(2) norden

Utvärdering av Nordiskt Nätverk för Vuxnas Lärande 2015-2016 





\section{Utvärdering av Nordiskt Nätverk för Vuxnas Lärande 2015-2016}

Sofia Nyström, Song-ee Ahn och Fredrik Sandberg 
Utvärdering av Nordiskt Nätverk för Vuxnas Lärande 2015-2016

Sofia Nyström, Song-ee Ahn och Fredrik Sandberg

ISBN 978-92-893-4713-6 (PRINT)

ISBN 978-92-893-4714-3 (PDF)

ISBN 978-92-893-4715-0 (EPUB)

http://dx.doi.org/10.6027/TN2016-544

ISSN 0908-6692

(C) Nordiska ministerrådet 2016

Layout: Hanne Lebech

Omslagsfoto: Scanpix

Tryck: Rosendahls Schultz-Grafisk

Printed in Denmark

Denna rapport är utgiven med finansiellt stöd från Nordiska ministerrådet. Innehållet i rapporten avspeglar inte nödvändigtvis Nordiska ministerrådets synpunkter, åsikter eller rekommendationer.

www.norden.org/nordpub

\section{Det nordiska samarbetet}

Det nordiska samarbetet är ett av världens mest omfattande regionala samarbeten. Det omfattar Danmark, Finland, Island, Norge och Sverige samt Färöarna, Grönland och Åland.

Det nordiska samarbetet är politiskt, ekonomiskt och kulturellt förankrat och är en viktig partner i europeiskt och internationellt samarbete. Den nordiska gemenskapen arbetar för ett starkt Norden i ett starkt Europa.

Det nordiska samarbetet ska stärka nordiska och regionala intressen och värderingar i en global omvärld. Gemensamma värderingar länderna emellan bidrar till att stärka Nordens ställning som en av världens mest innovativa och konkurrenskraftiga regioner.

\section{Nordiska ministerrådet}

Ved Stranden 18

DK-1061 København K

Telefon (+45) 33960200

www.norden.org 


\section{Innehållsförteckning}

Innehållsförteckning...................................................................................................... 5

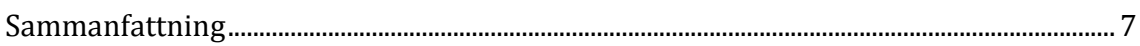

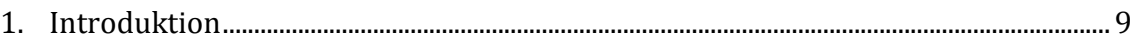

1.1 Samverkan, nätverk och mätning av effekter...................................................... 9

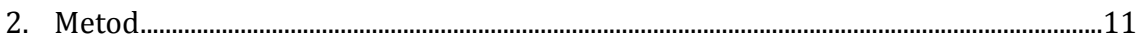

2.1 Sammanställning av informanter ........................................................................12

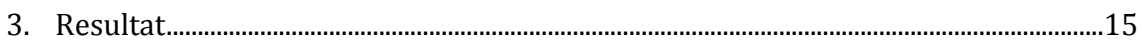

3.1 Huvudkoordinator, nationella koordinatorer och kontaktpersoner ............15

3.2 Nationell koordinator och kontaktpersoner - att leda nätverk......................16

3.3 Att arbeta och lära i nätverk …………….............................................................20

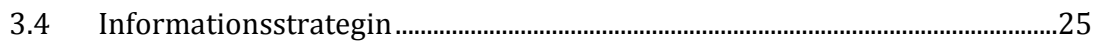

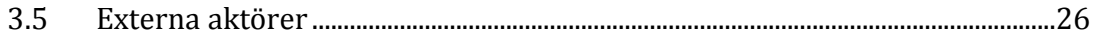

3.6 Effekter av NVL..........................................................................................................27

3.7 NVL:s styrkor, svagheter, utmaningar och möjligheter...................................31

4. Sammanfattande diskussion och rekommendationer..................................................37

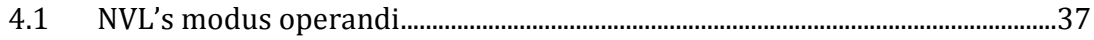

4.2 Informations- och kommunikationsstrategin .....................................................42

4.3 Väntade och oväntade effekter ...............................................................................4

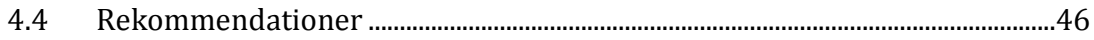

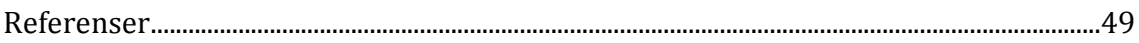

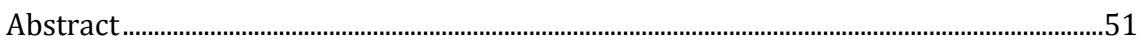

Bilaga 1a - Intervjuguide för huvudkoordinator .................................................................53

Bilaga $1 \mathrm{~b}$ - Intervjuguide för nationell koordinator samt nätverkssamordnare...........55

Bilaga 1c - Intervjuguide för webbredaktör ......................................................................57

Bilaga 1d - Intervjuguide för fokusgruppintervju..............................................................59

Bilaga 1e - Intervjuguide för externa intervjupersoner......................................................61 



\section{Sammanfattning}

Syftet med utvärderingen av Nordiskt nätverk för Vuxnas Lärande (NVL) är främst att få kunskap om NVL:s styrkor och svagheter, organisationsformens möjligheter och utmaningar samt nätverkens aktiviteter, spridning och bidrag i Norden. En annan aspekt som tas upp är NVL:s effekter gällande nordiskt mervärde och dess bidrag till kvalité och innovation samt policy- och praxisutveckling i Norden. Utvärderingen grundar sig på intervjuer med koordinatorer, webbredaktör, externa experter. I utvärderingen gjordes också fokusgruppsintervjuer med nätverksmedlemmar. Resultatet av utvärderingen visar att NVL drivs av kunniga och engagerade medlemmar. Deras arbete präglas av flexibilitet, självständighet samtidigt som NVL styr dem genom gemensamma målsättningar. Att nätverk består av medlemmar från flera olika nordiska länder gör att NVL bidrar till ett individuellt lärande, men även till en kollektiv kunskapsutveckling och spridning samt ett regionalt lärande inom Norden. En av de framtida utmaningarna är att hantera tidsbrister bland medlemmarna och att se till att det sker en hållbar utveckling av nätverken. Det efterfrågas också en tydligare koppling mellan nätverkens arbete och policyutveckling i de Nordiska länderna i relation till frågor om vuxnas lärande. 



\section{Introduktion}

Nordiskt nätverk för Vuxnas Lärande (NVL) har funnits sedan 2005 och deras arbete knyter ihop experter, inom olika områden för vuxnas lärande, i ett gemensamt nordiskt samarbete. Avdelningen för pedagogik och vuxnas lärande, Institutionen för beteendevetenskap och lärande (IBL), Linköpings universitet, har på uppdrag av Nordisk Ministerrådet (NMR) utvärderat NVL. Utvärderingens syfte är att få kunskap om NVL:s modus operandi, styrkor och svagheter, organisationsformens möjligheter och utmaningar samt nätverkens/arbetsgruppers aktiviteter, spridning och bidrag i Norden. Vidare diskuteras NVL:s effekter gällande nordiskt mervärde, dess bidrag till kvalité och innovation samt policy- och praxisutveckling i Norden.

För att utvärdera NVL har universitetslektorerna Sofia Nyström (projektledare), Song-ee Ahn och Fredrik Sandberg gjort intervjuer med koordinatorer, NVL:s webbredaktör, nätverk, externa personer med anknytning till NVL.

\subsection{Samverkan, nätverk och mätning av effekter}

NVL organiseras som en paraplyorganisation över ett antal nätverk och arbetsgrupper. Därav är det viktigt att studera vilken betydelse dessa nätverk har för hur deltagarna samt organisationerna förhåller sig till NVL och de effekter som eventuellt kommit ur detta sätt att organisera verksamheten. Tidigare forskning har identifierat samverkan i nätverk som en förutsättning för lärande och utveckling (Cressey, 2006; Holmquist, 2010; Wistus, 2010). Forskning om samverkan i nätverk visar resultat på individnivå, men det finns vissa svårigheter att få till ett organisatoriskt lärande eller implementering av resultat på lång sikt. Svårigheterna med att nå varaktiga förändringar på organisationsnivå förklaras ofta med att organiseringen i sig innebär att den frikopplas från medlemmarnas ordinarie verksamhet - en frikoppling mellan nätverk och ordinarie verksamhet som skapar svårigheter att implementera resultat i ordinarie verksamhet (Jensen \& Trägårdh, 2012; Swan, Scarbrough \& Newell, 2010). Idag organiseras samverkan mer på regional nivå till exempel i form av intermediärer och kompetensplattformar (Asheim, 2012). Bland annat beskriver 
Asheim (2012) lärande regioner som ett begrepp som har kommit att bli populärt både i forskning och på policynivå. Begreppet lärande regioner handlade från början framförallt om att förklara och skapa förutsättningar för regional samverkan för att generera innovationer och konkurrenskraft i regionens näringsliv, såsom i denna utvärdering, Norden. Med lärande regioner utgår man fråntanken att samverkan skapar lärande och innovation för att stärka regionens konkurrenskraft, ekonomiska tillväxt, arbetsmarknad och sociala sammanhållning. Betydelsen av lärande regioner och de antaganden som begreppet inrymmer har kommit att bli centralt i EU:s strategier för regional utveckling.

I takt med att det har vuxit fram nya sätt att organisera för utvecklingssatsningar på regional nivå har det förts en debatt kring hur resultat och effekter av dessa satsningar kan studeras och utvärderas (Svensson, Brulin, Jansson \& Sjöberg, 2009; Tarschy, 2011). Utvärdering är centralt i offentlig politik och förvaltning. Effekter har traditionellt setts som konsekvenser som uppkommit som resultat av den insats som har utförts och som är önskade i relation till uppsatta mål eller andra värdekriterier (Vedung, 2009). I debatten har kritik riktats mot mål- och planeringsstyrda modeller för utvärdering, då syftet med dessa insatser till stor del är att pröva nya metoder och lösningar i arbetsmarknadspolitik och regional tillväxtpolitik (Svensson \& Brulin, 2013). Forskning påvisar att effekter kan vara både väntade och oväntade, önskade och oönskade eller rakt motsatta det som avsetts och planerats för i målen (Svensson \& Brulin, 2013; Vedung, 2009).

Mot bakgrund av diskussionen kring svårigheterna att identifiera och utvärdera effekter av insatser som syftar till utveckling, lärande eller innovation, har nya utvärderingsmodeller utvecklats. Dessa fokuserar på hur effekter uppstår och sammanhangets betydelse för uppkomsten av effekter (Patton 2010; Svensson et al., 2009). Denna rapport är en utvärdering och knyter an till samma perspektiv genom att inkludera både väntade och oväntade effekter. 


\section{Metod}

För att få kunskap om NVL:s modus operandi, styrkor och svagheter, organisationsformens möjligheter och utmaningar, samt nätverkens/arbetsgruppers aktiviteter, spridning och bidrag i Norden var det viktigt att inhämta information främst inom, men också i viss mån utanför, NVL.

För att studera effekterna av NVL:s arbete och spridning har nyckelpersoner identifieras inom, men också delvis utanför, organisationen. Med nyckelpersoner menar vi de i ledande positioner såsom huvudkoordinatorn, nationella koordinatorer (vilka även är nätverkens samordnare), kontaktpersonerna för Åland och Färöarna samt NVL:s webbredaktör. Sammanlagt genomfördes nio intervjuer med centrala nyckelpersoner (se tabell 1). Med dessa individer har vi genomfört individuella djupintervjuer för att få kännedom om deras arbete inom NVL samt organisationens styrkor, svagheter, möjligheter och utmaningar. Intervjuerna genomfördes i samband med nätverksmöten eller på personens kontor och varade mellan 50 minuter och en och en halv timme. Tre intervjuer genomfördes dock via Skype p.g.a. stora geografiska avstånd, samt svårigheter att hitta en gemensam tid för intervju.

Nätverken har en central position inom NVL och för att få del av nätverksmedlemmarnas uppfattningar om nätverkets arbete och dess effekter har vi genomfört 10 fokusgruppsintervjuer (1-7 deltagare per nätverk). Fokusgruppsintervjuerna har genomförts i samband med nätverksmöten både "face-to-face" och via Adobe Connect och varade mellan 50 minuter och en och en halv timme (se tabell 1 för en översikt över samtliga fokusgruppsintervjuer). Förutom detta har deltagande observationer på ett nätverksmöte per nätverk genomförts. Observationerna ligger inte till grund för utvärderingen, utan syftet var att få en uppfattning om hur nätverken organiserar sig, vad de arbetar med och fă exempel på vilka aktiviteter som sker inom nätverken. Totalt har vi genomfört åtta observationer med en omfattning av ca: 33 timmar. Då två nätverk inte hade några träffar under vår tid för datainsamling fick vi inte möjlighet att observera något av dessa möten. 
Vidare har vi studerat befintliga och strategiska dokument såsom: såsom Informations- och kommunikationsstrategin 2015-2017 (NVL, 2015), utvärderingen av NVL 2012 (Danmarks Evalueringsinstitut, 2012) och exempelvis verksamhetsplaner. Vi har även studerat dokumentation på NVL:s och nätverkens hemsidor, för att få en förståelse för hur och vad organisationen, samt nätverken, kommunicerar mot allmänheten.

Vi har även identifierat externa aktörer utanför NVL som har kännedom om organisationen och dess arbete. Vi såg det som angeläget att intervjua dessa nyckelpersoner utanför NVL:s organisation för att få kunskap om, samt ett annat perspektiv på, NVL:s spridning, uppdrag samt effekter i Norden. Dock visade det sig vara svårt att få dessa personer att medverka och därav har endast två externa aktörer intervjuats. Den ena intervjun genomfördes på NMR och den andra via Skype. För att få en överblick över vilka personer vi har intervjuat se tabell 1.

Vi tog initial kontakt med alla informanter via ett mail där vi beskrev utvärderingen, vilka vi var samt frågade om de hade möjlighet att delta. Alla informanter var väldigt tillmötesgående och vi kunde boka tid för intervju.

Själva intervjuerna, både individuella och forkusgrupper, ägde rum med stöd av intervjuguider. Intervjuguiderna var till del lika men formulerades något olika beroende på informantens arbete och relation till NVL (se bilagor 1a, b, c, d, e).

Analysen har tagit utgångspunkt i NVL:s styrkor, svagheter, möjligheter och utmaningar (SWOT), samt potentialer för framtiden. Fokus har även varit på att identifiera och diskutera både väntade och oväntade effekter av NVL:s arbete. Utvärderingen har därmed följt en formativ utvärderingsmodell, där fokus är på NVL:s framtida utveckling.

\subsection{Sammanställning av informanter}

\subsubsection{Interna inom $N V L$}

Enskilda intervjuer. Informanternas namn och funktioner:

- Antra Carlsen, huvudkoordinator.

- Svante Sandell, nationella koordinatorer samt nätverkssamordnare.

- Pirkko Sartoneva, nationella koordinatorer samt nätverkssamordnare.

- Ellen Stavlund, nationella koordinatorer samt nätverkssamordnare. 
- Sigrún Kristín Magnúsdóttir, nationella koordinatorer samt nätverkssamordnare.

- Maria Marquard, nationella koordinatorer samt nätverkssamordnare.

- Viveca Lindberg, kontaktperson samt nätverkssamordnare.

- Elisabeth Holm, kontaktperson.

- Johanni Larjanko, webbredaktör.

\subsubsection{Fokusgruppsintervju}

Nätverk och antal deltagare i fokusgruppsintervju:

- Alfaråd: 1.

- Nordiskt Distansnätverk: 4.

- Nordiskt nätverk för fängelseutbildning: 6 .

- Nätverket kompetens ur ett arbetslivsperspektiv: 7.

- Nordiskt expertnätverk för validering: 6 .

- Nordiskt nätverk för vägledning: 5.

- Nordiskt nätverk för entreprenörskap: 2.

- Nätverk för Ö-samarbete: 3 .

- Arbetsgrupp för baskompetenser: 5 .

- Lärande för hållbar utveckling: 2 .

\subsubsection{Extern utanför $N V L$}

Enskilda intervjuer. Informantens namn och funktion:

- Malene Vangdrup, internationell rådgivare, Uddannelses- og Forskningsministeriet.

- Helle Glen Petersen, seniorrådgivare, NMR. 



\section{Resultat}

I denna del kommer resultatet av utvärderingen att beskrivas. Idén i denna del är att ligga nära intervjupersonernas svar på de frågor som skrevs fram i utvärderingsuppdraget. Således kommer frågor som rör arbetssättet i NVL vara centralt. Vi presenterar resultatet i en hierarkisk ordning där vi börjar med huvudkoordinator, landskoordinatorer och kontaktpersoner. I nästa del fokuseras nätverken och sist kommunikationsstrategin samt intervjuer med externa individer. Vidare framläggs effekter, utmaningar och möjligheter, styrkor och svagheter i ett gemensamt avsnitt.

\subsection{Huvudkoordinator, nationella koordinatorer och kontaktpersoner}

I denna del presenterar vi resultatet av intervjuer med koordinatorer och kontaktpersoner. Vi inleder med huvudkoordinatorn för att sedan beskriva resultatet av intervjuer med nationella koordinatorer och kontaktpersoner.

\subsubsection{Att leda NVL - Huvudkoordinator}

Det centrala arbetet för huvudkoordinatorn är att planera hela NVL utifrån NMR:s mål och se till att alla förstår detta på samma sätt, samt knyta ihop nätverken och ha en blick över helheten. Huvudkoordinatorn påpekar att det är många människor i nätverken, som alla kan dra åt olika håll, och det är därmed viktigt att ha en god överblick. Framförallt handlar det om att ha kunskap om nätverkens resultat.

\subsubsection{Arbetssätt och stöd}

Huvudkoordinatorn träffar övriga koordinatorer 4-5 gånger per år, utöver detta har de måndagsmöten on-line varannan vecka. Arbetet beskrivs av samtliga koordinatorer som ensamt, vilket visar på vikten av att ha tät kontakt med andra koordinatorer. Huvudkoordinatorn har vidare sin fasta arbetsplats på VOX (Nasjonalt Fagorgan for Kompetensepolitikk) i 
Oslo där det också finns en kontaktyta. Här finns ett stöd, NVL:s ekonomi och arkiv. Huvudkoordinatorn får också stöd från seniorrådgivaren på NMR. Huvudkoordinatorn talar om att NVL ibland är något för litet när det gäller vissa frågor och i vissa fall behövs extra stöd från NMR.

Rent praktiskt träffar huvudkoordinator nätverken med ca ett och ett halvt års mellanrum. Huvudkoordinatorn har vidare kontakt med värdorganisationer i varje land och träffar dem ca 2-3 ggr om året för att diskutera, bland annat, ekonomi. I egenskap av huvudkoordinator är ansvaret också att ha kontakt med EK-U (Embedsmandskomiteen for Uddannelse og Forskning) och NMR. Exempelvis informera EK-U kring NVL:s arbete, men det finns i nuläget inte någon djupare diskussion dem emellan. Kontakt sker också ut mot Europa för att synliggöra NVL:s arbete. Huvudkoordinatorn är också representerad på olika konferenser som anordnas inom ramen för NVL. I dessa fall är ofta uppdraget att inleda eller avsluta dessa i form av föreläsningar. Att arbeta som huvudkoordinator innebär också att vara tillgänglig och resa. Även om en del arbete görs on-line, är de fysiska träffarna viktiga. Huvudkoordinatorn påpekar att denne drivs av att arbetet är spännande och roligt. En annan viktig del är det lämnas mycket självständighet gällande metoder och former för arbete

\subsection{Nationell koordinator och kontaktpersoner - att leda nätverk}

Förutom huvudkoordinator så styrs NVL av fem nationella koordinatorer (Sverige, Norge, Danmark, Finland och Island) och tre kontaktpersoner i självstyrda regioner (Färöarna, Åland och Grönland). I varje land och självstyrda region, finns det en värdorganisation för NVL och utsedda nationella koordinatorer/kontaktpersoner som arbetar i denna organisation. De nationella koordinatorerna och kontaktpersonerna har en bakgrund och yrkeserfarenheter som är relevanta för vuxnas lärande, vuxenutbildning och/eller har de haft ett starkt intresse för området. Erfarenheten och intresset gör att dessa personer visar ett stort engagemang och en stark drivkraft vilket krävs för att göra ett gott arbete. Sammantaget medför uppdraget som nationella koordinatorer och kontaktpersoner att de är länkar mellan NVL och sina respektive nationer/självstyrda regioner samt länkar mellan NVL:s olika nätverk.

Utifrån intervjuerna med de nationella koordinatorernas framkommer det att deras arbete är viktigt för att NVL ska uppnå sina mål, exempelvis gällande informations- och resultatspridning samt synliggörande av NVL på olika nationella arenor. De fungerar som en mellanlänk och 
kunskapsbärare till och från NVL. Detta arbete yttrar sig på olika sätt dels genom att de håller sig uppdaterade på vad som sker inom vuxnas lärande nationellt och dels genom att sprida och informera om NVL:s arbete och resultat. För att synliggöra arbetet inom NVL så organiserar de seminarier och/eller konferenser där de bjuder in nationella nyckelpersoner på området. Men, det kan även handla om att de deltar i olika nationella sammanhang för att själva sprida vad NVL gör. De nationella koordinatorerna/kontaktpersonerna påpekar att de gör ett tvärsektionellt arbete, då både arbetet med nätverken och deras samarbetspartners är från olika sektorer. Vidare har de i sitt uppdrag att förse NVL med statistik gällande olika områden kring vuxnas lärande. De ska även följa med utvecklingen i sina respektive nationella kontexter och utifrån det tänka strategiskt kring vad NVL kan bidra med.

De nationella koordinatorerna och kontaktpersonerna har även i sitt uppdrag att arbeta som nätverkssamordnare för NVL:s nätverk. Hur många nätverk de ansvarar för beror på hur stor del av deras tjänst som innefattas av NVL. De nationella koordinatorerna arbetar $50 \%$ medan kontaktpersonerna arbetar $25 \%$, vilket medför att de nationella koordinatorerna har större ansvarsområden och koordinerar fler nätverk.

\subsubsection{Arbetssätt och stöd}

I intervjuerna framkommer att arbetet som nationell koordinator och kontaktperson för de självständiga regionerna karaktäriseras, i hög grad, av flexibilitet och självständighet. Arbetet betyder att de ska och kan planera och styra mycket av det egna vardagliga arbetet. Informanterna påpekar att arbetet har gett dem personliga utvecklingsmöjligheter och ett stort kontaktnät gällande vuxnas lärande, vilket är ett stort värde som kommer med uppdraget. Men de betonar även att det är ett ensamarbete, då de är ytterst ansvariga för NVL i sitt land. Förutom det vardagliga arbetet så har de tät kontakt med huvudkoordinatorn, de andra koordinatorerna och kontaktpersonerna. De träffas "face-to-face" fyra till fem gånger per år och sedan har de måndagsmöten on-line varje vecka med huvudkoordinatorn. På så sätt har de täta kontakter med andra koordinatorer. De visar stor tillit till huvudkoordinatorn, dennes kunskap och engagemang.

Samtidigt behövs ständigt stöd och tillgång till olika arenor för att de ska kunna utföra sina uppgifter på ett tillfredsställande sätt. Även om de har bra stödstruktur inom NVL, räcker det dock inte för att utföra arbetet utan de behöver även stöd från ett nationellt sammanhang. Tillgången till eller avsaknaden av ett nationellt sammanhang har en avgörande betydelse 
för de nationella koordinatorerna och kontaktpersonerna. Vilket stöd och vilken tillgång till olika arenor och nationella sammanhang som informanterna har, varierar och beror på värdorganisationen och personers egna nätverk samt kontakter. När det gäller värdorganisationen, d.v.s. koordinatorernas och kontaktpersonernas arbetsgivare, påpekas det att NVL borde tänka på vilken organisation som ska vara värdorganisation. Detta är viktigt då koordinatorer och kontaktpersoner betonar att de behöver ha tillgång till olika och relevanta arenor och aktörer för att sprida NVL:s resultat nationellt, samt få tillgång till nationell information för att uppdatera NVL om vad som sker nationellt. Personligen arbetar de mycket för att hitta ett mer naturligt sätt att närvara i olika sammanhang där NVL:s arbete är relevant. Detta för att på så sätt synliggöra och stärka NVL:s position. Några av dem påpekar att vuxnas lärande inte alltid är ett prioriterat område i det nationella utbildningssammanhanget och som koordinatorer eller kontaktpersoner får de kunskap om vilka svårigheter som är relaterade till vuxnas lärande i deras nation eller region. I intervjuerna blir det tydligt att koordinatorerna bjuder in nordiska experter till sammanhang för vuxnas lärande genom NVL. På ett sådant sätt bidrar de till att bilda och stärka nordiska kontakter i sitt land och sin region, vilket blir värdefullt för utvecklingen inom området.

Vissa koordinatorer anordnar nationella möten med nätverksmedlemmar från olika NVL nätverk, med syftet att främja informationsbyte och synliggöra NVL:s arbete. Möten såsom dessa kan även vara viktiga när koordinatorerna ska rekrytera nationella medlemmar till de olika nätverken.

\subsubsection{Att leda nätverk}

En viktig del av koordinatorernas och kontaktpersonernas uppdrag är att vara nätverkssamordnare. Vem som ansvarar för vilka nätverk verkar bestämmas på olika sätt, men en viktig aspekt är koordinators/organisations kompetens kring ämnet. De flesta fick "ärva" sitt nätverk som deras företrädare hade ansvar för, d.v.s. de nationella koordinatorerna eller kontaktpersonerna som arbetade för NVL innan dem. Ett annat sätt är att den arbetsgrupp som de arbetat med, fick ett utvidgat ansvar och omvandlas till ett NVL-nätverk. I dessa fall kan de fortsätta ta ansvar som nätverkssamordnare. I andra fall bestäms det utifrån hur mycket arbete de övriga koordinatorerna har. Detta resulterar i att de inte alltid får ansvar för nätverk som arbetar med ett område i vilket de, personligen, har kunskap om. Detta upplevs som både positivt och negativt av koordinatorer. Att ha för mycket kunskap kan leda till att man 
engagerar sig alltför mycket i arbetet. Samtidigt kan det också vara positivt att ha kunskap och förståelse i ämnet, då detta underlättar kontakten och arbetet med nätverken.

Att vara nätverkssamordnare kräver mycket tid då arbetet innebär olika ansvarsområden på olika nivåer. Som nätverkssamordnare tar de hand om det praktiska innan, under och efter mötet, t.ex. bokning av lokaler, hotell, flygbiljetter, skriva dagordning och hantera minnesanteckningar. De ska också balansera rollen mellan att vara sekreterare och ordförande under mötet; när ett möte flyter på bra så kan de inta en mer tillbakadragen roll medan det kan krävas att de tar en ledande och styrande roll i vissa sammanhang. Det handlar då om att få till ett beslut eller för att få till ett avslut på en långdragen diskussion. Som nämnts ovan så träffas nätverken både "face-to-face" och online. Koordinatorer betonar att det är deras ansvar att se till att de fysiska mötena också blir "lite extra och något utöver det vanliga". De brukar därför försöka anordna någon social aktivitet i samband med mötena. Detta för att visa att de, och indirekt NVL, värdesätter medlemmars engagemang. Vidare betonar de att det är viktigt att mötena ska hålla hög kvalitet och vara effektiva så att deltagarna inte känner att de "sitter av" möten utan att det tvärtom ska ge något tillbaka.

En viktig funktion är att koordinatorerna ska vara en länk mellan nätverket och NVL i stort. Som nätverkssamordnare hjälper de nätverken att identifiera sina prioriteringsområden, samt att nätverkets mål och aktiviteter ligger inom NVL:s övergripande mål och ramar. Nätverkets eget intresse och agenda måste på så sätt kombineras med NVL:s. Varje nätverk skriver sin egen verksamhetsplan och den ska kopplas till de fyra huvudmålen med NVL. Det uppskattas att dessa mål är öppna och vida så att det finns utrymme för tolkningar och olika inriktningar utifrån varje nätverks intressen. I intervjuerna framkom även att koordinatorerna och kontaktpersonerna förhåller sig till NMR:s plan och mål.

Det poängteras i intervjuerna att det är viktigt att det finns utrymme för att nätverken ska kunna utveckla och driva sin prioriterade agenda, så länge som den ligger inom ramen för NVL:s övergripande mål. Denna flexibilitet bidrar till att NVL blir en dynamisk organisation där"många blommor får blomma". Som nätverkssamordnare påpekar de att deras nätverk uppnår målen även om de inte uppfyller alla mål lika väl.

Det är nätverkssamordnarna som identifierar möjliga samarbeten mellan olika nätverk och presenterar idén för nätverksmedlemmarna. Men de är mycket noggranna med att påpeka att det är nätverket som får bestämma om det blir ett samarbete eller inte. Generellt tycker de att de olika nätverken har många gemensamma punkter, kring vilka de skulle 
kunna samarbeta, vilket ligger som en del av NVL:s strategi. Dock påpekar de att det i själva verket inte är enkelt att starta ett samarbete mellan nätverken p.g.a. den tidbrist som nätverksmedlemmarna upplever. De påpekar också att nätverksmedlemmarna inte alltid ser någon anledning till samarbete. Emellertid så visar nätverkssamordnarna en stor respekt för nätverksmedlemmars arbetstid, då NVL inte betalar för deras engagemang och arbete i form av lön.

\subsection{Att arbeta och lära i nätverk}

I denna del presenteras resultatet av intervjuerna med nätverken. De presenteras sammanhållet, då fokus är att lyfta fram det generella i hur nätverken arbetar.

\subsubsection{Att organiseras i nätverk}

Nätverken och dess deltagare utgör kärnan i NVL:s organisation. Idag finns det 10 nätverk där vissa är mer aktiva än andra. Vid olika tillfällen skapas också mindre arbetsgrupper som under en begränsad tid arbetar med ett specifikt projekt eller problemområde.

Medlemmarna i nätverken arbetar ofta på myndigheter eller i organisationer. I den tidigare utvärderingen visade det sig att en stor del av medlemmar arbetade på myndigheter eller forskningsinstitut (Danmarks Evalueringsinstitut, 2012). Vissa medlemmar har dessutom ett arbete som är direkt relaterat till nätverkets arbetsområde, men detta gäller inte alla medlemmar. Nätverken och arbetsgrupperna leds av en nätverkssamordnare.

I fokusgruppsintervjuerna med deltagarna från nätverken framkom att det finns olika orsaker till att de är engagerade i NVL. Vissa berättade att de blivit kontaktade av koordinatorn eller andra nätverksmedlemmar medan andra själva uppsökt nätverket för att bli medlem. Vissa berättade även att arbetet i nätverket ingår som en del i deras ordinarie arbetsuppgifter och att vissa på så sätt har ärvt medlemskapet från tidigare kollegor. De som uttrycker att de på ett sätt blivit "head-hunted" för att ingå i nätverket, betonar att de arbetar med frågor som rör nätverkets område eller att de har erfarenhet som efterfrågas. De individer som själva uppsökt nätverket uttrycker att de sökt efter ett sammanhang där de kan diskutera frågor som berör deras intresseområde. Ett annat sätt att bli medlem är att någon medlem slutar sin ordinarie tjänst och att dess efterträdare tilldelas uppdraget att verka i nätverket inom 
ramen för sin tjänst. Här kan vi se tendenser till att vissa nätverk byggt upp traditioner kring rekrytering.

Deltagarna betonar vikten av en bred kunskap och erfarenhet hos individerna i nätverken. Det lyfts fram att de ofta arbetar på nyckelpositioner inom respektive land och/eller arbetar med frågor relaterade till nätverkets syfte och mål. Bredden i deras erfarenhet och kunskap är viktig att bevara när nya medlemmar utses. Vidare påpekar de vikten av en balans mellan varaktighet och utveckling. Nya medlemmar tillför nya idéer och kunskap, men om flera medlemmar blir tvungna att sluta samtidigt finns det en risk att nätverket förlorar sammanhållningen och riktning, vilket påverkar nätverkens utveckling och hållbarhet. Här har koordinatorn en viktig roll att stödja nätverket i rekryteringsprocessen och därmed skapa stabilitet inom nätverken.

\subsubsection{Deltagande, engagemang och motivation}

I fokusgruppsintervjuerna framkommer att deltagarna är starkt engagerade och motiverade i sitt arbete inom NVL. Deras engagemang beskrivs med ord såsom eldsjälar och experter inom området och att de ser ett behov av att utveckla ett visst område eller att de saknar ett sammanhang för vissa frågor. Engagemanget yttrar sig i att de investerar sin tid, både arbetstid och egen tid, för att kunna delta och bidra. Deltagarna betonar att deras deltagande i första hand möjliggörs av att deras arbetsgivare låter dem, på arbetstid, delta i nätverksmöten. Men, deltagandet handlar ofta om att tid ställs mot tid, dvs. att arbetet som drivs utöver tiden då nätverket träffas, sällan ges specifikt utrymme i deltagarnas tjänster. Således får deltagarna ta av sin privata tid. Deltagarna påpekar vikten av ett personligt engagemang och intresse. Den nytta som kommer av att delta i nätverken ger så pass mycket tillbaka att medlemmarna accepterar knappa resurser. De prioriterar således arbetet i nätverket, även om det ofta påpekas att de upplever en tidsbrist.

Den enskilda individens organisatoriska hemvist har betydelse för deras deltagande och möjlighet att driva och arbeta med nätverkets frågor i sin vardag. En del av deltagarna har ett arbete som relaterar till nätverkets arbete, vilket gör att dessa individer har möjlighet att direkt integrera det som sker i nätverket i detta arbete. Detta gör att gränsen mellan nätverkets aktiviteter och deras arbete blir flytande. De individer som arbetar i ett sammanhang som inte berör nätverket, påpekar att de har svårigheter att få förståelse för sitt engagemang och intresse för NVL. I dessa fall blir nätverket en viktig arena där individen får kontakter och utbyte för sina intressen. Att ingå och arbeta i nätverket kan därav tolkas som att 
det ger den enskilda individen mycket tillbaka i form av ett nordiskt nätverk, kunskaper och utveckling. Utan detta skulle medlemmarna inte investera så mycket i sitt engagemang. Vidare påpekar de att deras arbetsgivare också har liknande förväntningar på att få något tillbaka såsom kontakter, nätverkande och kunskapsutbyte. Sammanfattningsvis påpekar deltagarna att NVL och NMR får mycket tillbaka för de resurser som tilldelas NVL. Det bör påpekas att utan nätverksmedlemmarnas engagemang hade inte resurserna räckt för deras arbetsinsats.

\section{Arbetsordning och arbetssätt}

Alla nätverk har liknande arbetssätt. De träffas på face-to-face tre till fyra gånger per år samt via on-line möten med Adobe Connect. Många nätverk säger också att de har tät e-postkontakt för att sköta det dagliga arbetet. Det praktiska innan och under mötet, såsom boka lokaler, hotell, flygbiljetter, skriva dagordning, minnesanteckningar, sköts av koordinatorn. Deltagarna menar att koordinatorn möjliggör att deras möten organiseras på ett effektivt och praktiskt sätt. I vissa fall, som med fängelsenätverket, har en organisation ansvar för nätverket under två år. Detta ansvar flyttas sedan runt. Det finns således lite olika interna lösningar i olika nätverk, men överlag följer de ungefär samma rutiner. Vidare är det brukligt att nätverken träffas på olika seminarium eller konferenser där t.ex. en medlem i ett land bjuder in andra medlemmar och experter för att presentera resultat. Förutom arbetet i nätverket menar medlemmarna att den sociala delen av att organiseras i nätverk är viktig. I samband med de fysiska nätverksmötena är det brukligt att medlemmarna och koordinatorn äter middag tillsammans och när tid finns arrangeras en social aktivitet. Dessa aktiviteter stärker sammanhållningen i gruppen. Medlemmarna betonar att nätverkens arbetssätt och möjligheten till att träffas möjliggörs av att NVL finansierar deras resor och logi - utan detta finansiella stöd skulle nätverken inte fungera på samma sätt. Detta stöd uppskattas högt, samt att NVL förser dem med en koordinator som hanterar det praktiska arbetet.

Tillsammans med koordinatorn så skapar nätverksmedlemmarna en verksamhetsplan där det skrivs ned vad de ska arbeta med under ett år, samt när och var de ska träffas. Denna plan diskuteras med huvudkoordinator och ska godkännas av EK-U. Verksamhetsplanen följs upp i en rapport där nätverken framlägger nätverkets resultat i relation till denna plan.

Förutom allt praktiskt runt mötena betonas vikten av koordinatorns roll som processdrivare i nätverksarbetet. Medlemmarna betonar att det är viktigt att koordinatorn är närvarande och engagerad i arbetet som sker, 
men samtidigt ska denne ge nätverket utrymme för kreativitet och låta dem driva de frågor som de anser viktiga. Vidare påpekas att det inte ses som avgörande om koordinatorn har kompetens i de frågor som nätverket driver, utan betoningen ligger på om de kan driva processen framåt eller inte. I de fall där koordinatorn har stor kunskap kring vissa frågor så menar deltagarna att de gärna ser att koordinatorn gör inspel och delar med sig av sin erfarenhet. Det påpekas även att koordinatorn har en viktig roll när det gäller relationen till NVL i stort och arbetet som sker i övriga nätverk. Koordinatorn informerar vad som sker i övriga nätverk, informerar om aktuella rapporter och lyfter frågor som gäller NVL i stort. Här betonas att koordinatorn har en viktig roll som informationsspridare.

Huvudkoordinatorn lyfts också fram som avgörande för nätverket och NVL i stort. Deltagarna i nätverket är samstämmiga när de påpekar att huvudkoordinatorn är både kunnig och engagerad i nätverkens interna arbete, samt driven i att sprida och arbeta för NVL i stort. Huvudkoordinatorn har en central roll och upplevs som "spindeln i nätet". Dock påpekar flertalet medlemmar att huvudkoordinatorns roll är skör då mycket är bundet till denne och ställer sig frågande till vad som skulle ske med NVL om denne slutade.

Gemensamt för nätverken är att de betonar att deras arbete sker mest "bottom-up", då de utifrån sin erfarenhet av praktiken kan identifiera områden som nätverket ska arbeta med. Utifrån att de delger varandra hur t.ex. situationen är i ett visst land, vilka problem som finns men även innovativa och tänkbara lösningar, så bildar de en gemensam förståelsegrund och utifrån det identifierar de områden eller problem som nätverket kan engagera sig i. Utifrån arbetet med olika områden är vidare förhoppningen att kunna påverka praktiken, men också myndigheter och politiker. Men, de betonar även att de mer och mer ser en vilja till "topdown" styrning då NVL vill påverka deras arbete. Bland annat lyfter deltagarna fram viljan från NVL:s sida till ett utökat samarbete mellan nätverken, samt ökat fokus på exempelvis rapportskrivande. Deltagarna påpekar att ett utökat samarbete är önskvärt och att de ser varför viljan finns. I flera intervjuer framkommer också att idén om samarbete måste bygga på relevans - det finns också exempel på sådana relevanta samarbeten, framförallt mellan distansnätverket och ett flertal andra nätverk (exempelvis fängelseutbildningsnätverket). Nätverk bjuder också in medlemmar från andra nätverk till konferenser och seminarier. Dock påpekas det att det är svårt att organisera och utveckla samarbete då de har knappa resurser. 


\subsubsection{Relationer och aktiviteter}

De aktiviteter som nätverken lyfter fram, är att de bedriver olika projekt som mynnar ut i rapporter. Exempelvis har Alfarådet producerat en folder kring illiteracitet som används flitigt av praktiker i flera nordiska länder. Valideringsnätverket har sammanställt en modell kring kvalitetsarbete inom validering, som under de närmsta åren kommer att testas praktiskt i Sverige, Danmark och Finland. Själva rapportskrivandet betonas vara en kollektiv process där nätverket tillsammans ansvarar för skrivandet eller att en grupp av personer ur nätverket driver skrivandet framåt. Rapportens innehåll skapas av nätverksmedlemmar men slutskrivande och/eller redigering kan avlönas extra. När en rapport är färdig så arbetar de med att sprida resultatet genom att anordna konferenser, seminarier etc. En viktig aspekt med dessa konferenser och seminarier är att bjuda in nyckelpersoner såsom politiker, utbildningsanordnare och intressenter från näringslivet för att på så sätt öka spridningen av resultatet.

Utifrån sitt engagemang i nätverken och den kunskap som individen får av att arbeta i nätverk så betonar medlemmarna att de blir som kontaktpersoner i sitt land gällande nätverkets intresseområde. När de ska arrangera någon aktivitet, öppen för flera eller specifik inom sin organisation, betonas att de alltid kan bjuda in andra nätverksmedlemmar att delta. Detta ger tyngd åt diskussionen och gör det lättare att lyfta frågor kring vuxnas lärande i Norden mer generellt. I detta sammanhang poängteras även vikten av andra nätverk och dess medlemmar då individens engagemang i NVL har lett till en medvetenhet om vilka som arbetar och driver frågor kring vuxnas lärande nationellt såväl som nordiskt.

På frågan om nätverket är en "ensam ö eller del av ett större system" framkommer olika svar beroende på hur länge nätverket har funnits och hur etablerat det är. Alla nätverk menar att de är en del av NVL och ser att arbetet de bedriver bidrar till att sprida och öka kunskapen om vuxnas lärande i Norden. Alla nätverk menar att den ekonomiska ersättning de får från NVL är avgörande för deras sätt att organisera sig. Om finansieringen skulle utebli menar de äldre nätverken att deras engagemang nu är större än NVL och att de på något sätt skulle försöka fortsätta nätverksarbetet även om NVL inte längre tilldelade resurser. 


\subsection{Informationsstrategin}

En del av utvärderingsuppdraget var att titta närmre på arbetet med kommunikationsstrategin som initierades 2015 och pågår till 2017 (NVL, 2015). Huvudkoordinatorn påvisar att kommunikationsstrategin kom till efter förra utvärderingen, där en av punkterna var att NVL ska synliggöra sina resultat på ett bättre sätt. Frågor kring denna strategi diskuterades under alla intervjuer, men i synnerhet med NVL:s webbredaktör, som är informations- och kommunikationsansvarig för informationsflödet ut från NVL. Detta uppdrag innebär en hel del praktiska uppgifter såsom att se till att NVL:s arbete publiceras på nätet, men innehåller också möjligheter att komma med förslag och bygga ut med nya tjänster. Det är detta som har fokuserats de senaste 1.5 åren. Mängdmässigt publiceras det mycket material, men detta når inte alltid de målgrupper som är definierade. Frågan är framförallt vilka kanaler som ska användas till vad och hur den kunskap NVL producerar görs attraktiv.

Sedan 2014 har NVL jobbat aktivt med att utveckla hur man sprider och kommunicerar den kunskap som produceras i nätverken. Exempelvis har man ökat sin synlighet i sociala medier såsom Twitter och Facebook, men också börjat använda exempelvis slideshare som är ett verktyg för att sprida konferenspresentationer, rapporter och dylikt. Vidare har ALFA-rådet och distansnätverket arbetat med att utveckla MOCCS. Tanken är att skapa möjligheter för en nordisk fortbildning. Möjligheten för att samla MOCCS i olika länder har undersökts och ett arbete med att göra workshops utifrån MOCCS har påbörjats. För detta ändamål har en arbetsgrupp med medlemmar från olika nätverk skapats, MOCCS arbetsgrupp. Detta arbete började för 2 år sedan och fortsätter till 2017.

NVL har också börjat arbeta mer "pushinriktat", vilket innebär att skapa intresse för den kunskap som genereras, jämfört med en tidigare mer "pullinriktad" strategi, där man främst arbetade med att föra ut kunskapen direkt. En utmaning är att öka den personliga närvaron i sociala medier, en annan är att framgent fortsätta att knyta ihop NVL som helhet (genom ex. en gemensam layout). Man har också arbetat med hemsidan och framförallt fokuserat på att få en större enhetlighet. Enligt webbredaktören är det viktigt att nätverkens hemsidor följer samma mönster och att nätverken hela tiden ser sig som del av en helhet. Således ska medlemmarna känna att de är med i ett gemensamt nätverk. Webbredaktören påpekar att det tar tid att bygga upp detta och under arbetet faller vissa medlemmar bort medan några kommer till vilket påverkar kontinuiteten.

Webbredaktören menar att det är en utmaning att knyta nätverken till NVL som helhet. De jobbar bra, men det finns utrymme för utveckling. 
I denna progression kan webbredaktören bidra med färska ögon och se synergier, samt få organisationen att bli mer informationsinriktad. Det handlar också om att visa på processer som är igång och få nätverk att ingå i diskussioner. Detta sker inte tillräckligt idag. Det handlar delvis om resurser. Webbredaktören har vidare arbetat direkt med medlemmarna för att få in deras synpunkter och försöker vara lyhörd för nätverksmedlemmarnas tankar.

\subsection{Externa aktörer}

Ett flertal externa individer med koppling till NVL kontaktades, men det var i slutändan endast två stycken som hade möjlighet att intervjuas. För utvärderingen intervjuades en individ som är internationell rådgivare, vid det Danska Uddannelses- og Forskningsministeriet och en som arbetar med NordPlus och därigenom har kontakter med NVL.

\subsubsection{Nordiska ministerrådets sekretariat}

I egenskap av seniorrådgivare intar denne en mer överordnad roll. Kontakten är framförallt med EK-U, som är styrgrupp för NVL. Som seniorrådgivare är man länken mellan NVL och EK-U och det är de som bestämmer övergripande vad NVL ska arbeta med. De avlägger vidare årsrapporter vilken seniorrådgivaren tar emot för att sedan anordnas ett möte med VOX där denna gås igenom. Det handlar framförallt om att titta närmre på om nätverken har gjort det de ska och använt pengarna på ett förnuftigt sätt. EK-U avvisar inte årsrapporten, men de kan ha åsikter kring hur NVL ska jobba i framtiden. Sista året har EKU haft ett ökat intresse för NVL och därmed önskat mer information om arbetet.

\subsubsection{Samarbetet mellan NordPlus, och NVL generellt}

Samarbetet med NordPlus tydliggör NVL:s relevans för Nordens gemensamma arbete med vuxnas lärande och det framkommer att man har nytta av att samarbeta med NVL. NVL och NordPlus samarbete formaliseras via ett kontrakt. De har ett årligt möte då de går igenom samarbetsavtalet. Deras samarbete handlar främst om informationsaktiviteter där NVL bidrar och understödjer Nordplus-projekt. De deltar också i informationsaktiviteteter tre gånger om året vilket ger möjlighet att ta del av det som händer inom NVL. NVL-nätverk har goda kontakter med vuxenut- 
bildningar runt om i Norden, vilket gör att om ett NordPlus-projekt behöver en partner så kan NVL vara en kanal. Vid ett sådant scenario tar huvudkoordinatorn kontakt med nätverk och knyter ihop dessa med NordPlus-projekt. Internationella rådgivaren ser relationen med NVL som viktig, men menar också att NordPlus program kan vara en kanal som bidrar med konkreta resultat som kan belysa problem som diskuteras i nätverken. Således ser Internationella rådgivaren relationen mellan NordPlus och NVL som ömsesidig, att båda program behöver varandra.

När projekt får pengar inom NordPlus används NVL som ett bollplank där NordPlus undersöker om det pågår arbete eller finns kompetens som kan stödja dessa projekt. När de ger pengar till konkreta projekt kan således NVL vara ett kunskapsstöd för dessa projekt. Men, det går också åt andra hållet, då NVL kan ha nytta av den kunskap som uppstår i NordPlusprojekt. Viktigt att påpeka är att NVL inte söker pengar från NordPlus som nätverk, däremot kan medlemmar söka pengar individuellt.

Sett från NordPlus och internationella rådgivaren, är det själva idén med nätverk som framhålls och att dessa tillsammans skapar en plattform för erfarenhetsutveckling mellan de nordiska länderna. Begrepp som utbyte av "best-practice" nämns i detta sammanhang. En annan bild som framkommer är länken mellan vuxnas lärande och livslångt lärande. Enligt internationella rådgivaren täcker NVL större delen av de fält som inbegrips i vuxenutbildning och stödjer därmed stora delar av det som inbegrips i begreppet livslångt lärande. En annan bild är den av NVL som ett öppet landskap där vyerna kan skifta och nya saker skapas, vilket kan ses som att NVL anpassar sig efter de behov som finns i praktiken och samhället.

\subsection{Effekter av NVL}

I avsnittet nedan presenteras resultatet med fokus på effekterna av det arbete som bedrivs inom och av NVL.

\subsubsection{NVL:s övergripande effekter i norden och kring vux- nas lärande}

När informanterna ska reflektera över NVL:s effekter så påpekar de att NVL har bidragit med att synliggöra vuxnas lärande genom att presentera olika nordiska lösningar, samt skapat mötesplatser och seminarier för att lyfta och aktualisera frågor. Huvudkoordinatorn påpekar att detta ger ett nordiskt mervärde, vilket uppstår när exempelvis tre länder har ett visst 
behov och arbetar tillsammans för att fundera ut lösningar. I detta arbete framkommer ofta goda exempel och man kan här lära av varandra - ett exempel är uppsökande vägledning som ska testas i ett flertal länder.

NVL, som helhet, kan tolkas som en tillgång i form av en kunskapsbas - en arena för utveckling och samling av erfarenheter. Detta blir speciellt viktigt för vissa regioner, t ex Färöarna, där vuxenutbildning/vuxnas lärande inte alltid är ett prioriterat område och det saknas en infrastruktur och organisering som andra större nordiska länder har. Detta medför att tillgång till NVL och dess nätverk får stor betydelse - inte minst för att lära av hur andra länder jobbar med frågor kring exempelvis livslångt lärande. Genom att ha (nationella) medlemmar i olika nätverk får regionen utbyte av erfarenhet och kunskap samt att nordiska experter har identifieras, vilka kan användas för att sprida resultat. NVL fungerar på så sätt som en tillgång till kunskap, erfarenheter, och utveckling.

Koordinatorerna och kontaktpersonerna menar vidare att NVL har stor betydelse och får effekter för de olika vuxenutbildningsarenorna i de nordiska länderna och de självstyrda regionerna. Det påpekas bland annat att NVL:s rapporter har stor spridning (t.ex. "Validation and value of competences - Roadmap" och "Ett nordisk perspektiv på karriärkompetenser och vägledning") och att de används flitigt i praktiken. Vissa koordinatorer och kontaktpersoner arbetar nära politiska organisationer och/eller politiker, till vilka de levererar relevant information och rapporter som har producerats av nätverk, med förhoppningen om att det ska påverka deras beslutfattande. Dock menar de att resultatet av NVL:s arbete borde kunna påverka beslutsfattare i högre grad. De påvisar dock att det är svårt att få till en naturlig kontakt med det politiska sammanhanget. Några föreslår att det är önskvärt att få dem som medlemmar i nätverken, så att de på så sätt blir involverade i arbetet. Det är tydligt att informanterna vill att kunskap som har producerats i NVL:s nätverk ska användas mer i beslutsfattning. Informanterna önskar också få kännedom om hur NVL:s resultat används utanför NVL. Denna typ av återkoppling till nätverk efterfrågas.

I intervjuerna så diskuteras att det är svårt att se dess påverkan på implementering och i form av politiska åtgärder. Utvärderingen visar att NVL har goda möjligheter att påverka praktiken kring hur vuxnas lärande organiseras, men har också potential att påverka myndigheter och policy. Nätverken har en ambition att påverka politiska beslut, bland annat utifrån att vissa nätverk blir inbjudna att medverka i skrivandet av policy på bland annat EU-nivå. Detta kan även ske indirekt via spridning och in- 
formation av de rapporter som nätverken producerar. De nationella koordinatorerna och nätverkets medlemmar påpekar dock att de har olika tillgång till politiska arenor.

I intervjun med de externa informanterna framkom att en potentiell effekt kan ses i policyinspel som kommit från nätverken till EK-U. Vidare kan EK-U styra över möjligheten att skapa effekter genom att bidra med extra resurser. EK-U gav exempelvis valideringsnätverket 630.000 DKK för att de ansåg att relevansen för validering är stark. Således kan resurser, i viss mån, allokeras till områden inom NVL som är extra relevanta.

\subsubsection{Effekter av att arbeta i nätverk samt effekter av själva arbetet}

Sammantaget är nätverksarbetet ett grundläggande nordiskt samarbete som gjort att det bildats relationer mellan och inom de nordiska länderna. Det som utmärker sig i intervjuerna är att de nordiska länderna är tillräckligt lika för att detta samarbete ska fungera, och samtidigt är de så pass olika att de kan lyfta fram exempel på olika lösningar, vilket visar på ett tydligt behov av att lära av och med varandra.

Utvärderingen visar att nätverkens arbete ger effekter på olika nivåer och på olika sätt. När det gäller de enskilda medlemmarna så har engagemanget bidragit till ökade kunskaper inom området. Vidare har arbetet i nätverket gett ett sammanhang och en kontaktyta för frågor kring vuxnas lärande. Individens deltagande medför även en kunskapsoch informationsöverföring in i deras arbetsorganisationen. Detta genererar effekter utifrån att frågor kring vuxnas lärande kan lyftas och diskuteras utifrån ett nordiskt perspektiv, vilket ger tyngd och legitimitet åt frågorna inom organisationen. Att ha tillgång till ett nätverk av experter har på så sätt stor betydelse för att stärka medlemmarnas arbetsorganisationer och sprida information om nätverkens arbete på olika arenor i nationellt och i Norden.

Vidare påpekar nätverkssamordnarna att nätverken och det arbete som sker i sig är en viktig effekt. Nätverken skapar ett naturligt möte mellan olika länder och individer/experter då medlemmarna utbyter erfarenheter, kunskaper, arbetssätt och lär sig av goda exempel. Nätverkens medlemmar arbetar alla med uppdrag eller i organisationer som är relevanta för nätverken och NVL. På så sätt sprids och förankras kunskap om vuxnas lärande ut i de nordiska länderna. NVL har varit och är framgångsrik i att skapa nätverk utifrån relevant problematik och områden samt att engagera med befintliga andra aktörer så att NVL:s röst finns i många sammanhang. 
Huvudkoordinatorn menar också att samarbete mellan nätverk är också mervärde. Det handlar då inte bara om utbildning utan också om kontakter kring den tematik som finns i nätverken. Exempel kan vara att ett arbete har bedrivits i ett nordisk land, när ett annat land kan följa processen och få goda exempel inför att de ska påbörja ett liknande arbete. Detta skapar rörelse mellan de nordiska länderna - kontaktnätverk och information flyter mellan länderna. Innovationer och utveckling i ett land kan således få effekter i andra länder. Nätverkssamordnarna påpekar vidare att NVL:s nätverk arbetar med kvalitet och innovation då de arbetar, planerar framåt och tänker brett om vuxnas lärande. Man kan också tänkta vissa nätverks uppkomst i sig är effekt av att tänka på vuxnas lärande på innovativt sätt, om vad som ingår i vuxnas lärande i dagens samhälle.

Detta ligger i linje med vad representanten för NordPlus menar - att just en av effekterna ligger i själva idén att skapa ett gemensamt nordiskt samarbete. Det ska genom detta samarbete i sig tillföra effekter. Informanten påtalar också att effekterna uppstår för att de Nordiska länderna är tillräckligt lika, men samtidigt mångfaldiga. I dissonanserna uppstår dynamiska relationer, när medlemmar från olika länder arbetar tillsammans. Det går således relativt effektfullt att överföra resultat mellan länderna för att ramarna är lika, men skulle det inte vara några skillnader mellan länderna skulle inte diskussionerna bli utmanande och därmed inte särskilt utvecklande.

Det finns också mer konkreta effekter. Som nämndes ovan har både ALFA-rådet och valideringsnätverket tagit fram material som konkret används av praktiker. Med informationsstrategin har NVL också satsat på att sprida material som produceras i nätverken på ett bättre sätt. Genom detta arbete synliggörs arbetet och når fler individer. ALFA-rådet påpekar att effekten handlar om att de har medverkat till att säkerhetsställa och ta fram kunskap och dokumentation. De påvisar att flera hundra lärare använder material de tagit fram, lärare från flera av de nordiska länderna. Materialet används i praktiken. De menar också att de får god bedömning av de lärare som använder materialet. De har också upplyst myndigheter om illiteracitet och för således ett arbete på flera plan. Å ena sidan mot praktiken å andra sidan mot relevanta myndigheter.

Nätverksarbetet resulterar sammanfattningsvis i en gemensam nordisk förståelseram via erfarenhetsutbyte i nätverken, produktion av olika rapporter, organisering av olika konferenser och seminarium där olika länders problem och lösningar ("best-practice") lyfts och diskuteras. Det är genom detta som NVL genererar effekter. 


\subsection{NVL:s styrkor, svagheter, utmaningar och möjligheter}

I intervjuerna fick alla frågor om NVL:s styrkor, svagheter, utmaningar och möjligheter. Det som var gemensamt för alla vara att de uttryckte en enighet kring att NVL har fått stor inverkan på dem som individer, i de grupper/organisationer de arbetar, nationellt och även i Norden.

\subsubsection{Styrkor och svagheter}

En av styrkorna som lyfts fram är just NVL:s arbetsform. I intervjuerna med huvudkoordinatorn, koordinatorerna och kontaktpersonerna så påpekas att de uppskattar arbetsformen som kännetecknas av låg grad av styrning och hög grad av självständighet samt flexibilitet. Det finns handlingsutrymme och öppenhet för nya idéer och detta skapar utrymme för kreativitet. Styrkan är således själva arbetssättet i sig - att arbeta utifrån idén om nätverk. Detta gör NVL till en dynamisk och innovativ organisation. De menar att NVL har en bra struktur, då arbetet är tvärnationellt och tvärsektionellt. Detta skapar goda mötesplatser. Nätverksmedlemmarna påpekar samma sak, då styrkan i nätverken är att de aktiva medlemmarna är experter inom sina respektive områden och som medlemmar visar på ett stort engagemang. Att sluta samman dessa individer i nätverk har visat sig vara lyckosamt. Nätverksorganisering blir på så sätt en naturlig mötesplats för utbyte av erfarenheter och kunskap. Medlemmarnas engagemang i produktion och spridning av kunskap har varit tydlig i utvärderingen samt i antalet rapporter som har skrivits. ${ }^{1}$

En svaghet som framkommer i de flesta intervjuerna är bristen på tid och begränsade resurser. Huvudkoordinatorn menar att det är svårt att hinna med allt - det krävs prioritering. Hur denna svaghet lyfts fram är olika. Eftersom nätverksmedlemmarna arbetar vid sidan om sitt arbete med NVL anser koordinatorerna att det är viktigt att sätta upp en tidsplan och respektera deras tid. Koordinatorerna påpekar att de själva upplever tidsbrist för sitt arbete. Att exempelvis kombinera arbetet med NVL med ordinarie arbete upplevs hos flera medlemmar som stressande. För kontaktpersoner är det tydligare. De måste hitta en balans när de arbetar med ett litet uppdrag men som samtidigt är intressant och relevant. Vidare påpekar koordinatorerna att deras uppdrag medför en hög grad av självständighet, vilket upplevs som både positivt och negativt. När det gäller resurser menar nätverksmedlemmarna att då NVL inte betalar för deras

${ }^{1} \mathrm{http}: / /$ nvl.org/Rapporter 
arbetsinsats så måste de legitimera den genom att visa på nyttan av nätverksarbetet för sina arbetsgivare. På så sätt är nätverken beroende av hur de kan producera nytta för berörda organisationer. Vissa medlemmar påpekar att om arbetsgivarna inte får något tillbaka så kan de förhindra deras medverkan. Medlemmarnas vilja och engagemang är starkt, men de känner, som nämnts ovan, att de inte har tillräckligt mycket tid för att alltid utföra ett bra arbete. Ett sätt som medlemmarna försöker att hantera detta på är att de försöker att inkludera projekt, som de inom sin arbetsorganisation arbetar med, i nätverksarbetet.

Medlemmarna i nätverken menar att de har en ganska god relation till NVL i stort och det är mycket tack vare nätverkssamordnaren. Det påpekas som en styrka gällande NVL:s arbetsordning. Dock menar de att det är ett skört system: vad händer när en nätverkssamordnare slutar och dess kompetenser försvinner?

Vidare säger en del nätverk att de är kritiska till NVL:s hemsida och hur spridningen av resultaten hanteras. I linje med informationsstrategin (2015-2017) så pågår nu ett utvecklingsarbete kring informationsspridning. Däremot är en svaghet att resurserna är begränsade, vilket kräver prioritering. Vidare så reflekteras det över hur NMR tar emot och arbetar med resultatet av NVL:s arbete. Det finns ett önskemål om en ökad tydlighet kring förväntningar och måluppfyllelse i relation till vad som produceras inom NVL, samt hur NMR ser på detta.

Utifrån ett externt perspektiv, vilket i detta fall är begränsat till två personer, kan man se att styrkorna med NVL också i viss mån är deras svaghet. Som nämndes ovan i relation till effekter är olikheter, vilka skulle kunna ses som en svaghet men också är en förutsättning för en stark dynamik. En annan svaghet som nämns är att det finns en risk att NVL tenderar att bli för abstrakt för en utomstående. Har man ingen kontakt med nätverken kan det vara svårt att förstå hur de fungerar. Enligt seniorrådgivaren är en svaghet gapet mellan praktik och EKU. Det är styrkan med hela nätverket att de som faktiskt vet något om det har maktfrågan är hur NMR i egentlig mening använder och tar till sig den kunskap som skapas inom NVL.

\subsubsection{Möjligheter och utmaningar}

NVL:s styrkor och svagheter flyter gärna ihop med diskussionen kring organisationens möjligheter och utmaningar. Huvudkoordinatorn ser möjligheterna med NVL som nästintill obegränsade. Resurser och tid begränsar förvisso, men påpekar att det finns ett starkt stöd från NMR . Det finns 
olika typer av utmaningar som koordinatorer och kontaktpersoner påpekar. Den första gäller deras arbetssituationer. Som beskrivits ovan påpekas att tidsbrist och ensamarbete ses som svagheter för deras arbetsvillkor. Att få tiden att räcka till för alla delar i deras uppdrag, samt att få andra engagerade i nätverk är en utmaning. Det påpekas att förordnande tidperiod är kort, vilket gör att det är svårt att planera sin tid och att skapa kontinuitet i deras arbete. Huvudkoordinatorn håller med och påpekar att en utmaning är att avgränsa arbetet och konkretisera det. De som är aktiva i NVL har mycket att göra och att prioritera är en utmaning. Vidare påpekar denne att en annan utmaning är att i nuläget stabilisera NVL och inte starta upp alltför många nya projekt. Huvudkoordinatorn ser detta som en viktig aspekt fram till 2018/2019 då det kan bli aktuellt att arbeta mer med utveckling. Detta berör även koordinatorerna då de menar att NVL:s fyra huvudmål fungerar som en bra ram för nätverksarbetet då de ger en hänvisning åt arbetet, samtidigt som de rymmer en öppenhet för tolkningar inom nätverken. En viktig fråga är om ett nätverk kan och måste uppfylla alla fyra mål. Det påpekas att samarbetet mellan olika nätverk kan utvecklas mer när det finns gemensamma beröringspunkter, men det är svårt att genomföra - främst på grund av tidsbrist. Att utveckla samarbetet mellan nätverk, så att olika nätverk får bättre relationer mellan varandra måste dock ses som en viktig utvecklingspotential för NVL.

Nätverkssamordnarna menar att de har ett ansvar och ser det som en utmaning att se till den "hållbara utvecklingen" hos deras nätverk, d.v.s. att hjälpa till nätverken att utvecklas. En viktig del är att nätverkens resultat ska användas för att föra nätverkets utveckling framåt och att kunskapen ska spridas och komma till användning. En annan utmaning är rekrytering till nätverken. Huvudkoordinatorn påpekar även vikten av att rekrytera medlemmar med annan etnisk bakgrund än nordisk. I en tid av ökad immigration till de nordiska länderna är det av stor vikt att rekrytera och få andra etniciteter representerade i NVL. Samtidigt är det en utmaning att rekrytera medlemmar av denna kategori. I detta sammanhang är det vidare av vikt att fundera hur NVL kan arbeta med andra etniska grupper. De senaste årens ökade invandring ställer stora krav på vuxenutbildning och NVL kan här medverka med sin kompetens. Även nätverksmedlemmarna reflekterar över själva sammansättningen av nätverken och menar att det är viktigt att inte förlora kompetens i nätverket. De påpekar vikten av att arbeta strategiskt med rekrytering av nya medlemmar. En annan utmaning som lyfts fram från nätverken är hur nätverken och NVL kan arbeta för att bevara nätverkets arbetsformer och det sociala lärandet som det innebär att arbete och verka i ett nätverk. 
Nätverkssamordnarna påpekar att de arbetar mycket för att NVL ska få större genomslag och vara en viktig aktör nationellt. De påpekar att det är viktigt men utmanande att hitta vägar. Vidare menar de att NVL är en komplicerad organisation. Det tar tid innan en enskilde nätverksmedlem får en klar uppfattning om NVL är. I intervjuerna framkom att nätverk borde vara mer integrerade i NVL mer i stort men hur detta samarbete ska kunna utvecklas är en stor utmaning, inte minst p.g.a. tidsbrist.

Vidare lyfts NVL:s uppdrag att arbeta brett med vuxnas lärande som en utmaning. I intervjuerna framkom att de nationella koordinatorerna och kontaktpersonerna behöver ha kunskap kring vilka som arbetar med eller har ett intresse för forskning kring vuxnas lärande, formell vuxenutbildning, universitet och högskola, arbetslivsutbildning och de övriga olika nationella systemen för vuxenutbildning när de försöker rekrytera folk till NVL. För att klara detta krävs en stor kontaktyta. Koordinatorerna och kontaktpersonerna har stora nätverk men det påpekas även att detta skulle kunna underlättas om värdorganisation de arbetar för vore en organisation som arbetar brett med vuxnas lärande.

Nätverken påpekar att önskan för mer samverkan inom NVL är bra, men att det måste ställas i relation till tidsbrist. Nätverken menar också att det finns kanske andra utmaningar som de som nätverk inom NVL borde fokusera på. Bland annat så identifierar nätverken samhälleliga utmaningar som de kan tänkas behöva arbeta med (ex. flyktingströmmen). En utmaning för nätverken är att hela tiden göra en omvärldsbevakning så att deras arbete blir aktuellt och att de bidrar med relevant kunskap.

NVL är ett grundläggande nordiskt samarbete. Även om det finns stark gemensamhet påpekar koordinatorerna att det även finns kulturella och språkliga olikheter som kan vara en utmaning. Språket inom NVL är de skandinaviska vilket i de flesta fall fungerar bra. I intervjuerna framkom att de finsktalande nätverksmedlemmarna ibland kan uppleva sig utanför då de inte kan delta i konversationerna på liknande villkor. När det gäller spridning av rapporter osv så översätts dessa ofta engelska så att de når alla i de nordiska länderna. Så arbetet med detta pågår redan.

Sammanfattningsvis är det viktigt att påpeka att det finns behov av diskussion kring hur resultat tas om hand och att tydliggöra förväntningar. En fråga som lyftes i nätverken är hur NVL generellt tar hand om den kompetens som utvecklas och allt som producerats. I linje med detta menar webbredaktören att precis som för nätverken och NVL generellt är det en utmaning att arbeta med relativt begränsade resurser. Även om NVL har utökat sin synlighet i social medier och börjat använda andra former av kanaler finns det en begränsning och det är inte möjligt att utnyttja flertalet av de olika kanaler som idag görs möjliga vi nätet. 
Det finns dock viss kritik av att hemsidan i nuläget inte uppfyller alla de behov som medlemmarna har.

Vidare diskuteras det generellt i intervjuer vad NMR förväntar sig av de resurserna som ges. De som arbetar för NVL investerar mycket tid och engagemang, samtidigt uttrycker de att det finns utökade krav och viljan av styrning medan de upplever att de inte har resurser för att möta kraven. När det känns för "tungt" och det inte finns handlingsutrymme eller nätverk känner sig mer styrda uppifrån finns en risk att NVL begränsar sina styrkor.

De utmaningar och möjligheter som lyfts fram från ett externt perspektiv är att även om det är tydligt att de möjligheter som NVL skapar är framträdande, framkommer det några utmaningar för framtiden. Utifrån ett NordPlus perspektiv är man väl medveten om NVL och vad de generellt gör i nätverken, men det framhävs också att NVL utifrån sett kan framstå som abstrakt. Det framkommer att det är flera institutioner som söker pengar från NordPlus varje år som inte vet något om NVL och vice versa. Då vuxenutbildningen är under press är en utmaning att samarbetet mellan institutioner förbättras. Det framkommer att NVL och NordPlus planerar ett seminarium 2017 för att utveckla kunskapen om de båda programmen. Detta att NVL kan framstå som abstrakt går här också att knyta an till informationsstrategin som är ett medel för NVL att förbättra synligheten och skapa en tydligare helhet. 



\section{Sammanfattande diskussion och rekommendationer}

Syftet med denna utvärdering var att få kunskap om NVL:s modus operandi, styrkor och svagheter, organisationsformens möjligheter och utmaningar samt nätverkens/arbetsgruppers aktiviteter, spridning och bidrag i Norden. Vidare berör utvärderingen NVL:s effekter gällande nordiskt mervärde, dess bidrag till kvalité och innovation samt policy- och praxisutveckling i Norden. I denna sammanfattande diskussion kommer vi att lyfta huvudresultaten och diskutera dem i relation till studier om effekter och lärande. Detta avsnitt avslutas med rekommendationer till NMR i relation till NVL.

\subsection{NVL's modus operandi}

\subsubsection{NVL:s arbetssätt, rutiner och metoder}

NVL består av en ledningsgrupp och olika nätverk och arbetsgrupper. Ledningsgruppen består i sin tur av huvudkoordinator, fem nationella koordinatorer och tre kontaktpersoner i självstyrda regioner, samt en webbredaktör. Ledningsgruppens arbete och rutiner verkar fungera bra. Anledningen till detta är att mötesstrukturen fungerar väl tillsammans med huvudkoordinatorns arbete att hålla gruppen samman. Dessa möten används som informations- och erfarenhetsutbyte. En utvecklingsmöjlighet som uttrycks är att även diskutera deras uppdrags innehåll och form samt utvecklingspotential.

Vuxnas lärande innebär en mångfald av kunskaper, där både formella institutioner och mer informella områden ingår. Att en person ska besitta kunskap kring alla relevanta områden är en omöjlig uppgift - nödvändigheten av stöd är därmed viktig. Det är därför angeläget för koordinatorer/kontaktpersoner att ha tillgång till nationella nätverk, organisationer och experter för att de ska kunna utföra sitt arbete. Vissa koordinatorer får denna tillgång genom den värdorganisationen som de arbetar i, där deras kollegor blir en viktig del och stöttning för deras arbete med NVL, medan andra använder sig av ett mer personligt kontaktnät som de har 
upparbetat genom åren. Vidare poängteras att andra nationella nätverksmedlemmar, organisationer och övriga nätverk också är ett viktigt stöd för dessa personers arbete för NVL. Då koordinatorernas/kontaktpersonernas arbete utgörs av flexibilitet och ett självständigt arbete ser vi det som viktigt att se över det stöd som dessa personer har samt vilken typ av organisation de arbetar i då det kan betyda mycket för deras möjligheter att utföra av uppdrag och få stöttning för sina arbetsuppgifter.

NVL:s sätt att organisera nätverk är framgångsrikt på många sätt och är en av de främsta styrkorna med NVL. Organiseringen har visat sig vara både effektivt och skapar effekter i form av nordiskt mervärde. Information och kunskap från de olika nordiska länderna med dess olika regioner möts och samlas i de olika nätverken. Detta blir till en nordisk kunskapsmassa som sprids via olika kanaler inom norden och i Europa. Detta är resultatet av hur nätverken konstitueras, d.v.s. att nätverken består av personer som har ett intresse, är forskare och/eller arbetar inom ett specifikt område inom vuxnas lärande. Vidare finns en representation av alla nordiska länderna. Detta är lyckosamt. Det finns dock en aspekt som denna utvärdering vill uppmärksamma och det är relationen mellan individens arbete i NVL:s nätverk och deras organisatoriska hemvist. Medlemmarnas deltagande i NVL möjliggörs av att deras arbetsgivare låter dem delta i nätverksaktiviteterna på arbetstid. Många nätverksmedlemmar uttrycker dock att de behöver förklara, samt ibland även försvara, sitt deltagande och arbete för NVL genom att visa vad arbetsgivaren får för nytta genom deras deltagande. Detta kan relateras till själva organisationsformen att arbeta i nätverk som är frikopplade från medlemmarnas ordinarie verksamhet (Jensen \& Trägårdh, 2012; Swan, Scarbrough \& Newell, 2010). Denna aspekt kan leda till spänningar om NVL försöker styra deltagarnas arbete i nätverken alltför hårt. Denna diskussion utvecklas ytterligare under nästa rubrik.

Utvärderingen visar att nätverkens mötesstruktur med en blandning av täta kontakter mellan medlemmar via digitala medier och regelbundna "face to face" möten är lyckosamt, inte bara för att vara effektiva och få ett bra arbetsresultat, utan att det också fungerar stärkande mellan nätverksmedlemmarna. Nätverkssamordnare försöker att dessa "face to face" tillfällen ska vara något "mer" än att mötas on-line för att förstärka den sociala samvaron i gruppen samt att ge nätverksmedlemmarna något tillbaka som tack för deras engagemang. Vidare försöker de även att kombinera nätverksmöten med andra NVL aktiviteter. Dess effekter ska inte underskattas. 
Vi vill även lyfta en diskussion kring NVL:s hållbara utveckling utifrån två viktiga punkter. Den ena punkten är rekryteringen av nya nätverksmedlemmar. Vissa nätverk har inte fått någon ny medlem på flera år, medan andra nätverk har bytt flera medlemmar på kort tid. Ingen av dem är idealisk för utveckling av nätverk. Ett nätverk behöver att nya medlemmar som kommer in med nya perspektiv och ett kritiskt förhållningssätt till varför saker görs som de görs men ett nätverk behöver även kontinuitet för att utvecklas. Den andra punkten gäller rekrytering och sammansättningen av ledningsgruppen. Det är inte överdrivet att konstatera att huvudkoordinator, de nationella koordinatorerna och kontaktpersoner är viktiga och avgörande för organiseringen av NVL. Detta då de fungerar som länkar inom NVL och dess nätverk men även ut mot den nationella och nordiska arenan kring vuxnas lärande. NVL kan upplevas som en komplicerad organisation som inte många har överblick över. Koordinatorerna fungerar som nätverkssamordnare för NVL:s många nätverk och dess medlemmar och är otroligt viktiga för det arbete som sker. Utvärderingen visar att deras arbete, förmågor och kompetens att skapa och underhålla relationer till medlemmarna har stor betydelse för nätverksarbetet och relationen mellan nätverket och NVL i stort. Många nätverksmedlemmar uppskattar att ledningsgruppen, och synnerligen huvudkoordinator, har ett stark engagemang och en hög kompetens i att hålla ihop nätverken. Det är positivt att nätverksmedlemmarna visar en stor tillit till nätverkssamordnarna, men de uttrycker även en viss oro kring vad som kommer att hända när en nätverkssamordnare måste bytas ut. Vidare uttrycker de liknande tankar kring huvudkoordinatorn för NVL och dennes erfarenhet och kompetens att leda NVL. NVL har nu funnits i 11 år och med tanke på hur NVL är organiserat så är den en, till stor del, personbunden organisation. Det är därav viktigt att börja förbereda för en generationsväxling och att utarbeta en plan för hur kunskapsöverföringen sker inom NVL, dess nätverk samt ledningsgrupp.

\subsubsection{Styrning av nätverken och arbetsgrupper}

I en tidigare utvärdering av NVL (Danmarks Evalueringsinstitut, 2012) konstaterades det att resultaten av omstruktureringen av NVL från lösare till stramare styrning var positiv. NVL styr nätverken via övergripande mål. I aktuell utvärdering går det att utröna att dessa mål upplevs som relevanta av både ledningsgrupp och nätverk. Både nätverkssamordnare och nätverksmedlemmar påpekar att nätverken själva bestämmer vad de ska arbeta med inom ramen för NVL:s mål. Målen beskrivs som formule- 
rade på ett sådant sätt att nätverken kan tolka dessa i relation till sitt arbete och därmed relativt fritt planera sina verksamhetsaktiviteter. Denna balans mellan generella mål och nätverkens frihet att kunna planera sin verksamhet är en viktig punkt. Det framkommer vidare i både intervjuer med nätverk samt koordinatorer att finns det en känsla av att NVL pressar på om samarbete för "samarbetets" egen skull. När det gäller relevanta samarbeten är det annorlunda. Det är då samarbete som har vuxit utifrån behovet att utreda eller utveckla något nytt tillsammans och därmed använda varandras erfarenheter. NVL har strävat efter att facilitera detta menar huvudkoordinatorn. Det är mycket viktigt att skilja på samarbete som växt fram utifrån behov och samarbete som krav. Även om nätverksmedlemmar ser samarbete som positivt finns det medlemmar som upplever en ökad styrning, samt ökade krav från centralt håll. Med redan små resurser är det viktigt att samarbete sker utifrån relevanta behov, så att resurserna kan användas så effektivt som möjligt. Det bör också påpekas att ett antal samarbetsprojekt givits resurser. ${ }^{2}$

NVL betalar inte för medlemmarnas arbete utan detta kan beskrivas som antingen frivilligt eller som sanktionerat av medlemmars arbetsgivare. Redan den tidigare utvärderingen (Danmarks Evalueringsinstitut, 2012) påpekade potentiella konflikter när NVL försökte styra nätverksarbetet från mer centralt håll. Detta kvarstår fortfarande. Flera medlemmar och koordinatorer ser en utveckling mot att de mer och mer måste förhålla sig till NVL:s övergripande mål. I aktuell utvärdering framkommer det att nätverkskoordinatorerna försöker balansera nätverkens röster och viljor med NVL:s krav. Det är av vikt att påvisa att en del av nätverksmedlemmarna beskriver att NVL försöker styra dem mer än tidigare och ställer mer krav i from av rapportering utan att mer resurser tilldelas. Detta är en viktig fråga då nätverken arbetar med praktiska problem och detta tvingar fram försök att prioritera hur man ska fördela tiden. Det är koordinatorerna som diskuterar vilka beröringspunkter olika nätverk kan tänkas ha och det är de som presenterar nätverksmedlemmar för idéer om samarbete. Det är en styrka att praktiskt konkreta problem får styra över nätverkens intressen och inte de abstrakta mål som NVL framtagit centralt. Nätverken är väl medvetna om dessa centrala mål och förhåller sig till dessa i sina verksamhetsplaner. Risken finns dock att dessa centrala mål blir alltför styrande. Det skulle riskera nätverkens kreativitet

2 Samarbete mellan vägledning och validering - arbetsgrupp, Budget 2014 - 70000 DKK; Budget 2015 70000 DKK. Samarbete mellan Distans och Alfarådet om MOOCs - Budget 2014 - 35000 DKK, Budget 2015 - 45000 DKK; Budget 2016 - 80000 DKK. Samarbete mellan Ö-nätverket och VuxPed \& Inovation - Budget 2016 - 170000 DKK. Samarbete mellan Distans och Vägledning kring IKT vägledning i självstyrda områden Budget 2016 - 180000 DKK. 
och stå i vägen för innovativa lösningar på konkreta praktiska problem. NVL är ett nätverk som existerar på grund av politiska beslut. Resurstilldelningen är skattepengar. Därmed är det självklart viktigt att centrala mål ska uppfyllas. I denna diskussion är det dock av vikt att balansera NVL:s övergripande mål med nätverkens frihet att kunna formulera sitt arbete utifrån konkreta problem i praktiken.

Sammanfattningsvis visar denna diskussion att styrningen av NVL via övergripande mål fungerar väl, men att många nätverksmedlemmar känner av en ökad styrning, samt ökade krav från centralt håll kring exempelvis samarbete. Detta utan att ytterligare resurser tilldelas.

\subsubsection{Medlemmarnas motivation och engagemang}

Det uppmärksammas i utvärderingen att alla som är involverade i NVL:s arbete, både ledningsgrupp och i nätverken visar en hög grad av motivation och engagemang för sitt arbete. Nätverksmedlemmar finner att deras arbete för NVL har hög relevans och bidrar till deras ordinarie arbete. Arbetet i NVL kan därav ses som en kompetensutveckling för medlemmarna då de påpekar att deras kompetens utvecklas i och med deras deltagande i ett nätverk. Denna kunskap tar de även med sig in i sina arbetsorganisationer där många av dem påpekar att ett det sker en verksamhetsutveckling utifrån att medlemmarna kan bidra med sin kunskap kring vuxnas lärande samt nordiska exempel samt att de även får möjlighet att använda deras ökade kunskaper. Den frikoppling mellan nätverk och ordinarie verksamhet som beskrivs inom forskningen framkommer inte i utvärderingen utan snarare att medlemmarna har möjlighet att implementera sina ökade kunskaper kring vuxnas lärande i ordinarie verksamhet. De uppskattar att nätverk även erbjuder en speciell möjlighet för möte och erfarenhetsutbyte med de andra som arbetar i samma område eller har liknande intressen inom vuxnas lärande. Utvärderingen visar att medlemmarna menar att arbetet med NVL har ett stort värde och de ser en stor nytta med NVL. Utifrån deras motivation och engagemang vill vi påpeka att NVL utifrån sin investering får mycket tillbaka i form av resultat och effekter.

Utvärderingen visar att det är ett beundransvärt arbete som görs, trots knappa resurser som inte motsvarar deras arbetstid. Dock vill vi lyfta fram tre aspekter som kan motverka deras engagemang och motivation. Den första är brist av resurser i formav tid. Både koordinatorerna och nätverksmedlemmarna påpekar att de arbetar mer än vad de får tid för. Den andra aspekten är när medlemmarna känner att NVL:s egen agenda t.ex. ett utökat samarbete mellan nätverk går före medlemmarnas 
egna intressen. Den tredje aspekten som framkommer är att de inte alltid känner sig uppskattade (se också Danmarks Evalueringsinstitut, 2012) för det arbetet som de utför. Vidare har de svårt att se vad deras arbete har lett till, $\mathrm{t}$ ex rapporterna som de producerar, vad händer med dem? Några ställer sig frågande till hur NMR arbetar med NVL:s resultat. Utvärderingen visar att formerna för återkoppling kan och bör utvecklas.

\subsection{Informations- och kommunikationsstrategin}

De senaste åren har det satsats på att utveckla kunskapsspridningen inom NVL, samt hur denna kunskap kommuniceras ut mot samhället. Exempelvis har man ökat sin synlighet i sociala medier såsom Twitter och Facebook, men också börjat använda exempelvis slideshare som är ett verktyg för att sprida konferenspresentationer, rapporter och dylikt. Vidare har ALFA-rådet och distansnätverket arbetat med att utveckla MOCCS. Tanken är att skapa möjligheter för en nordisk fortbildning. Möjligheten för att samla MOCCS i olika länder har undersökts och ett arbete med att göra workshops utifrån MOCCS har påbörjats. NVL har också börjat arbeta mer "pushinriktat", vilket innebär att skapa intresse för den kunskap som genereras, jämfört med en tidigare mer "pullinriktad" strategi, där man främst arbetade med att föra ut kunskapen direkt. Det är i nuläget svårt att utvärdera denna satsning, men det finns tydliga tendenser på att strategin har ökat möjligheten för utomstående att ta del av arbetet i NVL.

Genom denna strategi arbetar man också med att försöka hålla ihop NVL och få fram att det är en gemensam organisation, inte spridda nätverk med en vag koppling till NVL. Detta arbete tycks av vikt, men det innebär också att får med sig alla nätverken i detta arbete. Som vi återkommit till vid flera tillfällen är tidsbrist och resurser en tydligt uttalad problematik. Att lägga än mer ansvar på medlemmarna kan onekligen te sig problematiskt. Medlemmar har också riktat kritik mot hemsidan och koordinatorer har påpekat att de känner av en större arbetsbelastning i relation till att vara aktiv på exempelvis hemsidan.

Överlag är dock strategin nödvändig i ett samhälle där information tenderar att vara svårhanterlig. I en skattefinansierad verksamhet är det av ännu större vikt att kunskapen som skapas i NVL kommer praktiken och andra intressenter tillhanda. 


\subsection{Väntade och oväntade effekter}

I resultatdelen har vi presenterat de identifierade effekterna av NVL och arbetet som bedrivs. NVL är ett nätverk och därav en organisationsform som ligger utanför medlemmarnas ordinarie verksamhet. Forskning kring effekter visar att förutom effekterna gentemot måluppfyllelse, uppkommer ofta oväntade effekter (t.ex. Svensson \& Brulin, 2013; Vedung, 2009). Först kommer vi nu att diskutera effekter gentemot policy- och praxisutveckling, kvalité och innovation i Norden samt nordiskt mervärde. Därefter kommer vi att lyfta fram de mer oväntade effekterna i form av ett individuellt, organisatoriskt och regionalt lärande.

\subsubsection{Policy och praxis}

Ett av målen med NVL är att leverera underlag för policy till NMR och SVR. Vidare har många av nätverken ett uttalat mål och vilja att påverka policy. När det gäller de nordiska länderna är det landskoordinatorns uppgift att informera politiker och tjänstemän om NVL:s arbete och kunskapsproduktion. Enligt utvärderingen så tar koordinatorerna och kontaktpersonerna denna uppgift på stort allvar och de arbetar hårt för att nå ut och försöka påverka. Flera goda exempel har lyfts fram och det är tydligt att koordinatorernas/kontaktpersonernas organisatoriska hemvist samt personliga kontaktnät har betydelse. Även "närheten" till den politiska makten spelar roll och där har de självstyrande regionerna ett annat klimat än de övriga landskoordinatorerna. Det är tydligt att NVL producerar och levererar mycket resultat i form av bland annat rapporter och rekommendationer men det är svårt att uttala sig om dessa används eller påverkar policy. Vissa koordinatorer och nätverksmedlemmar påpekar också att om NVL ska vara en kraft som påverkar policy ska det behövas starkare och naturligare relation till "policy makers". När det gäller NMR så är det deras ansvar att ta kontakt med NVL för att nyttja den kunskap som finns inom NVL. Enligt utvärderingen så finns det utvecklingspotential här.

Praxisutveckling som effekt av NVL sker både direkt och indirekt. Direkt genom att nätverken kopplar an sina resultat till praxis i form av exempelvis verktyg såsom foldrar eller rapporter. Indirekt sker det genom att nätverksmedlemmarna för med sig sin kunskap tillbaka till sina arbetsplatser, vilket påverkar praxis lokalt. Det finns också exempel, såsom "To do seminars" som utvecklas inom nätverk och sedan praktiserats samt utvecklas. I intervjuerna med nätverken träder det fram att mycket av nätverksarbetet handlar om att presentera och jämföra hur nationerna och självstyrda regioner arbetar med ett specifik ämne. Som det påpekats 
tidigare, är samarbete mellan Norden fruktbart och dynamiskt för att de länderna och regionerna delar många likheter, t.ex. de kan lätt hitta gemensamma beröringspunkter i samhälleliga fenomen och samtidigt för att det finns tillräckligt mycket olikheter i hur olika nationer och regioner arbetar. Detta skapar en viktigt dynamik. Nätverken blir en naturlig arena för utbyte av erfarenheter och reflektioner vad som är bra och kan förbättras - genom detta förfarande utvecklas praxis i olika sammanhang.

\subsubsection{Kvalitet och innovation}

När det gäller kvalitén på det som produceras inom NVL så varken kan eller ska utvärderingen uttala sig men däremot så vill vi framhålla den kompetens och drivkraft som de personer som är engagerade i NVL både uttrycker och ger sken av. Vidare är NVL synligt i många relevanta sammanhang gällande vuxnas lärande i Norden. Detta är tecken på att NVL håller hög kvalité. Detta gäller både hur det är organiserat och det som produceras, då NVL har lyckats att engagera individer med ett intresse för vuxnas lärande, som arbetar inom området. Att intressera och hålla personer engagerade under 11 år är en bedrift. En aspekt av att NVL har lyckats så bra är den innovativa organisationsformen. NVL en tydlig ledningsgrupp som har i uppgift att sprida NVL:s arbete samt hålla ihop nätverken. Dessutom har de lyckats att organisera ett nätverk av kunniga och kompetenta individer.

Att samverka i nätverk menar flertalet forskare är en förutsättning för lärande och utveckling (Cressey, 2006; Holmquist, 2010) och NVL-nätverken verkar inte vara ett undantag då alla engagerade i nätverken framhåller sitt lärande. Detta kommer att diskuteras nedan. Vidare vill vi påpeka vikten av att inte endast se till vad som produceras inom nätverken utan även att de olika nätverken och de problem som de riktar in sig motmedför att vuxnas lärande problematiseras på ett innovativt sätt. Detta möjliggörs av nätverksarbetsformen som kännetecknas av ett flexibelt arbetssätt där nätverken snabbt kan svara på och börja arbeta med aktuella samhälleliga problem. På så sätt kan nätverken arbeta med områden inom vuxnas lärande som varit delvis ignorerat eller outvecklat. Nätverkens bidrag blir därav en breddning av området för vuxnas lärande samt vuxenutbildningens roll i det nordiska samhället. För att behålla denna höga kvalité och innovativa arbetsform behöver NVL, precis som nämns ovan, fundera över strategier för rekrytering av nya medlemmar till nätverken och se över kunskapsöverföringen inom ledningsgruppen och utveckla strategier för generationsskifte. 


\subsubsection{Nordiskt mervärde och lärande}

De mer oväntade effekterna som vi har sett utifrån utvärderingen kan relateras till NVL:s nordiska mervärde och lärande. Som vi har behandlat ovan så framhålls och poängteras det att en av de främsta effekterna av NVL är det individuella lärandet. Men lärande sker aldrig isolerat från det sociala sammanhanget och utvärderingen visar att det individuella lärandet grundar sig i det erfarenhetsutbyte och "peer-learning" som sker i och mellan nätverken inom NVL. Detta är en oväntad effekt. Vidare ser vi att att medlemmarnas geografiska spridning, organisatoriska hemvist samt nätverkens spridning inom området för vuxnas lärande bidrar till en ökad kunskapsnivå i Norden. Vi vill här lyfta fram begreppet lärande region (Asheim, 2012) utifrån att utvärderingen visar att NVL kan ses som en samverkansorganisation har det skapats ett lärande och en innovation som stärker och bidrar till ett nordiskt mervärde. Det är tydligt att NVL har skapat länkar mellan de nordiska länderna, samt att det finns ett flöde och utbyte av kunskap som inte kunnat möjliggöras utan NVL - åtminstone inte på samma sätt och säkerligen inte med samma goda resultat.

\subsubsection{Livslångt lärande}

Vi vill avslutningsvis påpeka att vi lever i en tid där livslångt lärande har en given plats i flertalet diskussioner såsom inom exempelvis utbildning, samt kring anställningsbarhet och arbete. Begreppet är dock inte entydigt. Snarare är betydelsen bred och därmed är det inte helt enkelt att definiera detta rent konkret. Länken mellan vuxnas lärande och livslångt lärande är stark inom NVL. I intervjuerna framkommer det att större delen av de fält som inbegripes i vuxenutbildning finns representerat i NVL. Därmed finns stora delar av det som inbegrips i begreppet livslångt lärande också representerat. Livslångt och livsvitt lärande är termer som påvisar att individen lär hela livet och i flera olika sammanhang. Att studera i fängelse, lära sig ett nytt språk som immigrant eller få sitt tidigare lärande validerat är alla aspekter av det livslånga lärandet. Således är strategierna för livslångt lärande naturligt inbyggt i det arbete som nätverken bedriver. Från en generell politisk definition av livslångt lärande går det att följa detta in i nätverkens olika ämnesområden där begreppet kan ses bli alltmer konkret: brottsdömda som läser in kurser och försöker göra sig anställningsbara; vårdbiträden som får sitt tidigare lärande validerat och kan anställas som undersköterskor (det livslångt lärandet går här också tillbaka till individens tidigare erfarenheter); lärare som får kompetensutveckling i illiteracitet som sedan undervisar immigranter som ställer om inför ett nytt liv i Norden. Allt detta påverkas av det som 
sker inom ramen för NVL och en av styrkorna är att arbetet sker utifrån de praktiska utmaningar som nätverken fångar upp i vuxenutbildningens olika kontexter.

\subsection{Rekommendationer}

Utifrån den genomförda utvärderingen kring NVL:s modus operandi, styrkor och svagheter, organisationsformens möjligheter och utmaningar samt nätverkens/arbetsgruppers aktiviteter, spridning och bidrag i Norden vill vi göra följande rekommendationer:

- Vi anser att NVL ska få fortsatt förtroende att driva sin verksamhet, då organisationen på olika sätt bidrar till att stärka fältet vuxnas lärande och de olika områdena för vuxenutbildning i Norden.

- En av de stora utmaningarna som framkommer i utvärderingens resultat är hur resurser kan ses i ljuset av ambitionsnivå. Det framkommer med tydlighet att både medlemmar och koordinatorer tampas med tids- och resursbrister. Vi rekommenderar att resurserna till NVL inte sänks, då aktörerna i NVL redan idag kämpar med att hålla en god ambitionsnivå.

- Nätverken utgör kärnan i NVL:s verksamhet. Utvärderingen har visat att nätverken har olika karaktär och svarar upp till NVL:s övergripande mål på olika sätt. Detta är viktigt då de berör olika aspekter av vuxnas lärande. Det finns tendenser till en ökad styrning av nätverken, vilket är bra för att forma verksamheten och få NVL att arbeta mot samma mål, men det är också viktigt att nätverken får behålla sin karaktär och sitt innovativa arbetssätt. Kraven på koordinatorerna har också ökat, vilket syns tydligt i resultat av utvärderingen. NVL bör se över de krav som åläggs koordinatorerna och se till att resurserna används på bästa sätt. För att bevara kreativiteten och nätverkens förmåga att lyfta och arbeta med praktiska problem så råder utvärderingen att nuvarande grad av styrning och krav är tillräckliga.

- Utvärderingen visar att medlemmarnas engagemang och motivation är en av de faktorer som gör NVL till en stark organisation. Dock påpekas att brist på resurser, speciellt i termer av arbetstid, motverkar detta och flera av nätverksmedlemmarna uttrycker att de är stressade. Ett sätt att underlätta medlemmarnas arbete och som även rekommenderades i tidigare utvärdering är att minska NVL:s 
ambitionsnivå i förhållande till resurser. Ett annat sätt är att NVL erbjuder en mindre ersättning till nätverken som kan användas för att t.ex. betala arbetstimmar för färdiggörande av en stor rapport.

- Utvärderingen visar att NVL bidrar till ett individuellt lärande, och även till ett kollektivt erfarenhetsutbyte, kunskapsutveckling och "peer-learning" inom och mellan nätverk. Därav pekar utvärderingen på att NVL bidrar till ett regionalt lärande inom Norden och detta med relativt små resurser. Det gäller att tillvarata och utveckla detta.

- I utvärderingen framkom att medlemmarnas arbetsorganisation uttrycker, eller att det upplevs, att de vill se resultat eller få återkoppling på medlemmarnas engagemang i NVL. Ett sätt är att se deltagandet i NVL som kompetensutveckling för dess medlemmar.

- Då NVL är något som sker utanför arbetsorganisationen, så behövs strategier för att det som produceras i nätverken, samt individens ökade kompetens, kommer till användning både inom och utanför organisationen. NVL har nu funnits i 11 år och är nu en väletablerad organisation med en fungerande ledningsgrupp. Utvärderingen har visat att frågan kring rekrytering av nätverksmedlemmar är en viktig fråga för utvecklingen av NVL, samt dynamiken inom nätverken. Vidare har vi lyft frågor kring generationsväxling av huvudkoordinatorn och de nationella koordinatorerna, samt kontaktpersonerna. För att NVL ska fortsätta att utvecklas föreslår utvärderingen att frågan kring rekrytering, generationsskifte och kunskapsöverföring lyfts för diskussion och planeras för.

- NVL och dess nätverks arbete resulterar i olika sorters rapporter och rekommendationer. Utvärderingen visar att formerna för spridning och återkoppling kan utvecklas. Inom NVL finns strukturer för hur återkoppling ges och sprids. Däremot har det påpekats att spridningen utåt kan ses över. T ex det betonas att NVL:s hemsida kan utvecklas för att underlätta samverkan och spridning av material. När det gäller återkoppling på utfört arbete samt resultatets effekter kan NMR tydliggöra hur de arbetar med, samt använder, NVL:s resultat.

- Avslutningsvis vill vi rekommendera att återanvända NVL:s organisations- och arbetsform inom andra delar av NMR då det är och har varit en stabil, utvecklande och kreativ organisering för lärande. 



\section{Referenser}

Asheim, B. (2012). The Changing Role of Learning Regions in the Globalizing Knowledge Economy: A Theoretical Re- examination. Regional Studies, 46(8), 1055-1066. http://dx.doi.org/10.1080/00343404.2011.607805

Cressey, P. (2006). Collective reflection and learning. From formal to reflective participation. I Boud, D. Cressey, P \& Docherty, P. (red) Productive Reflection at Work (s. 54-65). London: Routledge.

Danmarks Evalueringsinstitut (2012). Evaluering af Nordisk Netværk for Voksnes Læring (NVL). https://www.eva.dk/udgivelser/2012/evaluering-af-nordisk-netvaerk-for-voksnes-laering-nvl

Holmquist, M. (2010). Lärande nätverk. En social oas i utvecklingsprocessen. Akademisk avhandling. Luleå: Luleå universitet.

Jensen, C. \& Trägårdh, B. (2012). Temporära organisationer för permanenta problem. Om implementering av samverkansprojekt för unga som står långt från arbetslivet. Temagruppen Unga i arbetslivet 2012:1. Ungdomsstyrelsen i Stockholm.

NVL (2015). NVL:s informations och kommunikationsstrategi 2015 - 2017. http://nvl.org/Portals/0/Bilder/2015/NVL_Informationsstrategi_2015-2017.pdf

Patton, M, Q. (2010). Developmental Evaluation. Applying Complexity Concepts to Enhance Innovation and Use. New York: Guilford Publications.

Svensson, L. \& Brulin, G. (2013). Om effekter av program och projekt. I Svensson, L. Brulin, G. Jansson, S., Sjöberg, K. (red) Att fånga effekter av program och projekt. Lund: Studentlitteratur.

Svensson, L. Brulin, G. Jansson, S. \& Sjöberg, K. (2009). Lärande utvärdering genom följeforskning. Lund: Studentlitteratur.

Swan, J., Scarbrough, H. \& Newell, S. (2010). Why don't (or do) organizations learn from projects? Management Learning. 41(3), 325-344.

Tarschys, D. (2011). How Small are the Regional Gaps? How Small is the Impact of Cohesion Policy? A Commentary on the Fifth Report on Cohesion Policy. European Policy Analysis, Swedish Institute for European Policy Studies. 11(1), 1-6.

Vedung, E. (2009). Utvärdering i politik och förvaltning. Lund: Studentlitteratur.

Wistus, S. (2010). Det motsägelsefulla partnerskapet. En studie av partnerskap som organiseringsform inom EQUAL-programmet. Akad. Avh. Linköping: Linköpings Universitet. 



\section{Abstract}

The purpose of the evaluation is to gather knowledge concerning the strengths, weaknesses, opportunities and challenges of the organization Nordic Network for Adult Learning (NVL). More specifically, it puts emphases on the activities, distribution of the results and the organizations contributions in the Nordic region, with specific attention on the undertakings of the networks. Another aspect addressed in the evaluation are the effects of NVL's work regarding adding value to the Nordic region and its contributions to quality and innovation, as well as policy and practice development in Scandinavia. The evaluation is based on individual interviews with coordinators, the web editor and external experts. Focus group interviews were conducted with network members. The results show that NVL is managed and run by knowledgeable and committed members. Their work is characterized by flexibility and independence while at the same time being governed by shared and general objectives formulated by NVL. The network consists of members from all of the Nordic countries, which makes possible contribution to both individual learning as well as a collective knowledge development and dissemination. Thus, NVL contributes to a regional learning in the Nordic region. One of the future challenges is to manage the members time constraints and to ensure that there is a sustainable development of the networks. Furthermore, there is a need for a stronger link between the networks result and policy development in the Nordic countries in relation to issues of adult learning. 



\section{Bilaga 1a - Intervjuguide för huvudkoordinator}

1. Du är huvudkoordinator för NVL. Kan du börja med att beskriva vad denna roll innebär?

a. Hur kom det sig att du fick denna roll? Vad motiverar dig?

b. Vad arbetar du med i denna roll? Vad är det viktigaste med ditt uppdrag för NVL:s verksamhet? (informationsspridning, engagemang)

c. Hur arbetar du? Möten?

d. Vem stöttar dig i ditt arbete? Andra koordinatorer/andra på NMR?

2. Beskriv din roll och arbetet med nätverken:

a. Hur ser samarbetena mellan nätverken ut?

b. Om du tänker på de enskilda nätverken, hur relaterar de till NVL i stort? Hur ser kommunikationen ut?

3. Diskutera hur nätverkens arbete, metoder och aktiviteter bidrar till måluppfyllelse:

a. Om du tänker på din roller, vad kan du se som resultat av ditt arbete som främjar utveckling och implementering av olika strategier för livslångt lärande?

b. Ett av målen för NVL är att bidra till personlig utveckling och demokratiskt deltagande genom arbetet med frågor om vuxnas lärande. Hur förstår du detta mål? Vad kan du säga "så här arbetar vi för att nå detta mål”?

4. Beskriv samarbetet med Nordplus ramprogram. Hur ser detta samarbete ut?

a. Har nätverken arbetat med konkreta frågor kring att utvecklautbildningsinstitutioner i Norden?

b. Om du tänker på nätverken, hur sprider de sina resultat t.ex. nationellt, i Norden, Europa? Vem är målgruppen för ert arbete? 
5. Vi vill nu prata om NVL:s effekter. Om jag säger:
a. Nordiskt mervärde, vad tänker du på då? Exempel?
b. Utveckling av kvalitet och innovation i norden, vad tänker du på då? Exempel?
c. Policy och praxisutveckling i norden via land eller Nordiska mi- nisterrådet, vad tänker du på då? Eksempel?

6. Jag skulle nu vilja att vi diskuterar utmaningar och möjligheter, om du först tänker på din roll som huvudkoordinator, vilka möjligheter ser du där? Vilka utmaningar ser du? För NVL i stort?

7. I det här som vi har pratat om och ditt arbete åt NVL, är ditt arbete som du trodde att det skulle vara eller något annat? Hur? Vad?

8. Har du några övriga saker som du vill ta upp? Är det något ni tycker vi har missat som är av värde? 


\section{Bilaga 1b - Intervjuguide för nationell koordinator samt nätverkssamordnare}

1. Du är både nationell koordinator för NVL samt samordnare av nätverken . Kan du börja med att beskriva vad dessa två roller innebär?

2. För att hålla isär de båda rollerna, skulle jag vilja prata om er roll som nationell koordinator:

a. Hur kom det sig att du fick denna roll? Vad motiverar dig?

b. Vad arbetar du med i denna roll? Vad är det viktigaste med ditt uppdrag för NVL:s verksamhet? (informantionsspridning, engagemang)

c. Hur arbetar du? Möten?

d. Vem stöttar dig i ditt arbete? Andra koordinatorer?

3. Du är ju också nätverkssamordnare, hur arbetar du gentemot de nätverk som du är samordnare för?

a. Vad är din roll och uppgifter?

b. Varför är just du samordnare för detta/dessa nätverk?

c. Vem stöttar dig i ditt arbete? Andra samordnare? Nätverksmedlemmar?

4. Beskriv era roller och arbete i nätverket:

a. Vad arbetar ni med i nätverket?

b. Vem bestämmer innehåll, mål och syfte?

c. Hur arbetar ni i nätverken? Rutiner? Möten?

5. Samarbetar ni med några andra nätverk?

a. Hur kommer det sig att ni började samarbeta? Hur ser detta samarbetet ut?

b. Om du tänker på dessa samarbeten, vad har de lett till? 
6. Om du tänker på de enskilda nätverken, hur relaterar de till NVL i stort? Hur ser kommunikationen ut?

7. Diskutera hur ert nätverks arbete, metoder och aktiviteter bidrar till måluppfyllelse:

a. Om du tänker på din roller, vad kan du se som resultat av ditt arbete som främjar utveckling och implementering av olika strategier för livslångt lärande?

b. Ett av målen för NVL är att bidra till personlig utveckling och demokratiskt deltagande genom arbetet med frågor om vuxnas lärande. Hur förstår du detta mål? Vad kan du säga "så här arbetar vi för att nå detta mål”?

c. Samarbetar ni med Nordplus ramprogram? I så fall hur ser detta samarbete ut? Har ni arbetat med konkreta frågor kring att utveckla utbildningsinstitutioner i Norden?

d. Om du tänker på vad ni arbetar med i nätverken, hur sprider ni ert resultat t.ex. nationellt, i Norden, Europa? Vem är målgruppen för ert arbete?

e. Vi vill nu prata om NVL:s effekter. Om jag säger:

i. Nordiskt mervärde, vad tänker du på då? Exempel?

ii. Utveckling av kvalitet och innovation i norden, vad tänker du på då? Exempel?

iii. Policy- och praxisutveckling i norden via land eller Nordiska ministerrådet, vad tänker du på då? Exempel?

8. Jag skulle nu vilja att vi diskuterar utmaningar och möjligheter, om du först tänker på din roll som nationell koordinator, vilka möjligheter ser du där? Vilka utmaningar ser du? För NVL i stort?

9. Om vi då i stället talar om din roll som nätverkssamordnare och nätverkens arbete, vilka möjligheter och utmaningar ser du där?

10. Det här som vi har pratat om och ditt arbete åt NVL, är ditt arbete som du trodde att det skulle vara eller något annat? Hur? Vad?

11. Har du några övriga saker som du vill ta upp? Är det något ni tycker vi har missat som är av värde? 


\section{Bilaga 1c - Intervjuguide för webbredaktör}

1. Du är NVL:s webbredaktör. Kan du börja med att beskriva vad detta innebär?

2. Vilken roll har du i relationen med NVL?

a. Hur kom det sig att du fick denna roll/arbetsuppgifter?

b. Vad arbetar du med i denna roll? Vad är det viktigaste med ditt uppdrag i relation till NVL:s verksamhet? (informationsspridning, engagemang)

3. Har du kontakt med några specifika nätverk inom NVL?
a. Varför har just du kontakt med detta/dessa nätverk?
b. Hur kom du i kontakt med detta/dessa nätverk?
c. Vad är din uppgift/uppdrag i relation till detta?
d. Många av NVL:s nätverk har skrivit olika rapporter mm, har du tagit del av dessa eller någon annan information från nätverken?

4. Om du tänker på de enskilda nätverken utifrån din erfarenhet, hur relaterar de till NVL i stort? Hur ser kommunikationen ut?

5. Enligt din uppfattning, hur arbetar NVL med målet att främja utveckling och implementering av olika strategier för livslångt lärande?

a. Ett av målen för NVL är att bidra till personlig utveckling och demokratiskt deltagande genom arbetet med frågor om vuxnas lärande. Hur förstår du detta mål? Vad kan du säga "så här arbetar NVL för att nå detta mål"?

b. Hur ser samarbetet med Nordplus ramprogram ut med NVL:s nätverk? Hur ser detta samarbete ut? Har den arbetat med konkreta frågor kring att utveckla utbildningsinstitutioner i Norden?

c. Om du tänker på vad NVL och mer specifikt nätverken, hur har du kommit i kontakt med deras resultat? Vet du hur de sprider resultat t.ex. nationellt, i Norden, Europa?

d. Vem skulle du säga är målgruppen för NVL:s arbete i stort? 
6. Vi vill nu prata om NVL:s effekter. Om jag säger:
a. Nordiskt mervärde, vad tänker du på då? Exempel?
b. Utveckling av kvalitet och innovation i norden, vad tänker du på då? Exempel?
c. Policy- och praxisutveckling i norden via land eller Nordiska mi- nisterrådet, vad tänker du på då? Exempel?

7. Om vi tänker på NVL, vad är organisationens styrkor? Svagheter?

8. Om du tänker framåt, vilka möjligheter ser du för NVL i framtiden? Vilka utmaningar kan du se?

9. Har du några övriga saker som du vill ta upp? Är det något du tycker vi har missat som är av värde? 


\section{Bilaga 1d - Intervjuguide för fokusgruppintervju}

1. Berätta lite om er själva och varför ni har valt att engagera er i detta närverk.

2. Beskriv era roller och arbete i nätverket:

a. Vad arbetar ni med i nätverket? Vad är syftet med nätverket?

b. Hur bestäms innehåll, mål och syfte?

c. Hur arbetar ni i nätverken? Möten? Rutiner?

d. Finns det något som skulle underlätta ert arbete? Kanske göra det mer effektivt?

3. Samarbetar ni med några andra nätverk?

a. Hur kommer det sig att ni började samarbeta? Hur ser detta samarbetet ut?

b. Om ni tänker på dessa samarbeten, vad har de lett till?

4. Om ni tänker på nätverket, hur relaterar de till NVL i stort? Hur ser kommunikationen ut? Finns det något som går att förbättra i relationen med NVL?

5. Diskutera hur ert nätverks arbete, metoder och aktiviteter bidrar till måluppfyllelse:

a. Om ni tänker på det ni har arbetat med i nätverket, vad kan ni se resultat av ert arbete som främjar utveckling och implementering av livslångt lärande?

b. Ett av målen för NVL är att bidra till personlig utveckling och demokratiskt deltagande genom arbetet med frågor om vuxnas lärande. Hur förstår ni detta mål? Vad kan ni säga att "så här arbetar vi med för att nå detta mål”?

c. Har ni arbetat med konkreta frågor kring att utveckla utbildningsinstitutioner i Norden? (Samarbete med Nordplus ramprogram?).

d. Om ni tänker på vad ni arbetar med i nätverken, hur sprider ni ert resultat t.ex. nationellt, i Norden, Europa? Vem är målgruppen för ert arbete? 
e. Vi vill nu prata om NVL:s effekter. Om jag säger:

i. Nordiskt mervärde, vad tänker ni på då? Exempel?

ii. Utveckling av kvalitet och innovation i norden, vad tänker ni på då? Exempel?

iii. Policy- och praxisutveckling i norden via land eller Nordiska ministerrådet, vad tänker ni på då? Exempel?

6. Om ni nu tänker på ert arbete och aktiviteter i nätverket och utanför, vad är dess styrkor? Svagheter?

7. Om vi tänker framåt, vilka möjligheter för nätverket ser ni där? Vilka utmaningar ser ni? För NVL i stort?

8. I det här som vi har pratat om och ert engagemang i nätverket, kan ni ge något exempel på något resultat som ni inte hade väntat er? Vad? Hur kommer det sig?

9. Har ni några övriga saker som ni vill ta upp? Är det något ni tycker vi har missat som är av värde? 


\section{Bilaga 1e - Intervjuguide för externa intervjupersoner}

1. 1. Vi har kontaktat dig som en extern person som kan ha kunskap om NVL, hur kommer det sig tror du? Hur kommer du i kontakt med NVL i ditt arbete. Kan du börja med att beskriva vad detta innebär?

2. Vilken roll har du i relationen med NVL?

a. Hur kom det sig att du fick denna roll/arbetsuppgifter?

b. Vad arbetar du med i denna roll? Vad är det viktigaste med ditt uppdrag i relation till NVL:s verksamhet? (informationsspridning, engagemang).

3. Har du kontakt med några specifika nätverk inom NVL?

a. Varför har just du kontakt med detta/dessa nätverk?

b. Hur kom du i kontakt med detta/dessa nätverk?

c. Vad är din uppgift/uppdrag i relation till detta?

d. Många av NVL:s nätverk har skrivit olika rapporter mm, har du tagit del av dessa eller någon annan information från nätverken?

4. Om du tänker på de enskilda nätverken utifrån din erfarenhet, hur relaterar de till NVL i stort? Hur ser kommunikationen ut?

5. Enligt din uppfattning, hur arbetar NVL med målet att främja utveckling och implementering av olika strategier för livslångt lärande?

a. Ett av målen för NVL är att bidra till personlig utveckling och demokratiskt deltagande genom arbetet med frågor om vuxnas lärande. Hur förstår du detta mål? Vad kan du säga "så här arbetar NVL för att nå detta mål"?

b. Hur ser samarbetet med Nordplus ramprogram ut med NVL:s nätverk? Hur ser detta samarbete ut? Har den arbetat med konkreta frågor kring att utveckla utbildningsinstitutioner i Norden?

c. Om du tänker på vad NVL och mer specifikt nätverken, hur har du kommit i kontakt med deras resultat? Vet du hur de sprider resultat t.ex. nationellt, i Norden, Europa?

d. Vem skulle du säga är målgruppen för NVL:s arbete i stort? 
6. Vi vill nu prata om NVL:s effekter. Om jag säger:
a. Nordiskt mervärde, vad tänker du på då? Exempel?
b. Utveckling av kvalitet och innovation i norden, vad tänker du på då? Exempel?
c. Policy- och praxisutveckling i norden via land eller Nordiska mi- nisterrådet, vad tänker du på då? Exempel?

7. Om vi tänker på NVL, vad är organisationens styrkor? Svagheter?

8. Om du tänker framåt, vilka möjligheter ser du för NVL i framtiden? Vilka utmaningar kan du se?

9. Har du några övriga saker som du vill ta upp? Är det något du tycker vi har missat som är av värde? 
Nordiska ministerrådet

Ved Stranden 18

DK-1061 København K

www.norden.org

\section{Utvärdering av Nordiskt Nätverk för Vuxnas Lärande}

201-2016

Nordiskt nätverk för Vuxnas Lärande (NVL) har funnits sedan 2005 och deras arbete knyter ihop experter, inom olika områden för vuxnas lä-rande, i ett gemensamt nordiskt samarbete. Avdelningen för pedagogik och vuxnas lärande, Institutionen för beteendevetenskap och lärande (IBL), Linköpings universitet, har på uppdrag av Nordisk Ministerrådet (NMR) utvärderat NVL. Utvärderingens syfte är att få kunskap om NVL:s modus operandi, styrkor och svagheter, organisations $\neg$ formens möjligheter och utmaningar samt nätverkens/arbetsgruppers aktivite-ter, spridning och bidrag i Norden. Vidare diskuteras NVL:s effekter gäl-lande nordiskt mervärde, dess bidrag till kvalité och innovation samt policyoch praxisutveckling i Norden.

TemaNord 2016:544

ISBN 978-92-893-4713-6 (PRINT)

ISBN 978-92-893-4714-3 (PDF)

ISBN 978-92-893-4715-0 (EPUB)

ISSN 0908-6692

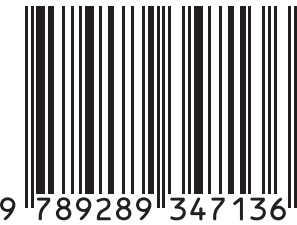

